\title{
Materialne podstawy utrzymania rodziny monarszej w Rzeczypospolitej szlacheckiej
}

\section{Materielle Grundlagen des Unterhalts der königlichen Familie im adeligen Polen}

1. Wprowadzenie. 2. Rodzina królewska jako instytucja. 3. Formy zaopatrzenia materialnego. 4. Źródła dochodów rodziny królewskiej w praktyce; 4.1. Źródła pozyskiwania dochodów; 4.2. Sposoby finansowania rodziny królewskiej; 4.2.1. Dobra ziemskie; 4.2.2. Nadania godności kościelnych; 4.2.3. Pensja; 4.2.4. Zapis sum; 4.3. Trwałość uprawnień majątkowych; 4.4. Podmiot uposażający; 4.4.1. Król; 4.4.2. Sejm. 5. Wplyw praktyki na ustawodawstwo; 5.1. Ustawodawstwo ograniczające prawo nabywania dóbr ziemskich; 5.2. Ograniczenia w zakresie nadawania godności kościelnych. 6. Wnioski.

1. Einleitung. 2. Die königliche Familie als Institution. 3. Materielle Grundlagen des Unterhalts. 4. Quellen des Einkommens der königlichen Familie in der Praxis: 4.1. Quellen des Einkommens; 4.2. Art und Weise der Finanzierung der königlichen Familie; 4.2.1. Landgüter; 4.2.2. Verleihung der kirchlichen Ämter; 4.2.3. Einkommen; 4.2.4. Schriftiche Zuteilung der Einkommen; 4.3. Dauer der Vermögensrechte; 4.4. Gehaltsgeber; 4.4.1. König; 4.4.2. Reichstag. 5. Einfluss der damaligen Realität auf die Gesetzgebung: 5.1. Gesetze über die Beschränkung hinsichtlich der Anschaffungen von Landgütern; 5.2. Beschränkung des Rechts hinsichtlich der Verleihung von kirchlichen Ämter. 6. Schlussfolgerungen.

Władcy Rzeczypospolitej Obojga Narodów wzbudzają ze zrozumiałych względów zainteresowanie badaczy, co znajduje odzwierciedlenie w licznych publikacjach poświęconym poszczególnym panującym ${ }^{1}$. Prawa i obowiązki monarchów polskich $w$ opiniach pisarzy Odrodzenia omówiła A. Sucheni-

\footnotetext{
1 Przykładowo wymieniamy: S. Grzybowski, Henryk Walezy, Wrocław-Warszawa-Kraków-Gdańsk 1980; J. B e sala, Stefan Batory, Warszawa 1982; H. Wis ne r, Zygmunt III Waza, Wrocław-Warszawa-Kraków 1991; Z. W ó j c i k, Jan Kazimierz Waza, Wrocław-Warszawa-Kraków 1997; A. Przyboś, Michal Korybut Wiśniowiecki 1640-1673, Warszawa 1983; Z. Wójci k, Jan III Sobieski 1629-1696, Warszawa 1983; J. Sta szewski, August II Mocny, Wrocław-Warszawa-Kraków 1998; t e nże, August III Sas, Wrocław 1989; Królowie elekcyjni. Leksykon biograficzny, red. I. Kaniewska, Kraków 1997.
} 
pozaprawny. Niewątpliwie zasługują na zbadanie metody stosowane np. przez władców dla zapewnienia swoim metresom i swojemu nieprawemu potomstwu materialnej pomyślności.

Nowo wybrany król zastawal z reguly w skarbie pustki ${ }^{12}$. Jednakże sytuacja materialna królewskiej rodziny $\mathrm{w}$ pierwszym rzędzie wynikała $\mathrm{z}$ wielkości zasobów oddanych do dyspozycji wladcy, który po wynagrodzeniu osób zasłużonych w walce elekcyjnej (wakującymi względnie odebranymi zwolennikom kontrkandydata starostwami i dzierżawami), często nie mial środków niezbędnych do zaspokojenia bieżących potrzeb ${ }^{13}$. Poza tym kurczyły się źródła dochodów. I tak np. trzy części dochodów z królewszczyzn, należne królowi od czasów egzekucji, zaprzestano płacić już Zygmuntowi III, mimo że ani on, ani jego następcy nie zrzekli się w tym zakresie swych praw ${ }^{14}$.

Ponieważ w rzeczywistości wladca elekcyjny (poza królami-rodakami ${ }^{15}$ ), w Rzeczypospolitej majątku prywatnego nie posiadał, a bieda królewskiego dworu niekiedy wręcz kompromitowała Rzeczpospolitą, podejmowane były działania zmierzające do zapewnienia władcy godnych warunków egzystencji. Służyć temu miały m.in. decyzje przyjęte na sejmach 1589 i 1590 r., kiedy wydzielono królewszczyzny (nazwano je ekonomiami), z których dochody były przeznaczone na utrzymanie panującego ${ }^{16}$. Wydzielenie ekonomii nie poprawiło na trwake sytuacji finansowej króla ${ }^{17}$. W tej sytuacji, gdy w aktach związanych $\mathrm{z}$ elekcją nie zwracano uwagi na to, że król posiada rodzinę, zapewnienie środków na utrzymanie niekiedy licznego potomstwa ${ }^{18}$ i wyma-

${ }^{12}$ O spustoszeniu skarbu po śmierci Zygmunta II Augusta i Stefana Batorego pisze A. F il i pczak - K ocu r, Z dziejów skarbu nadwornego za Zygmunta III Wazy, CPH 1986, t. XXXVIII, z. 1, s. 56 i n.; tejże, Finanse Rzeczpospolitej w latach 1587-1632, Zesz. Nauk. WSP w Opolu 1988, Historia XXVI, s. 28-30; tejże, Rozrzutny czy ubogi król Wladystaw IV, [w:] Dwór a kraj. Między centrum a peryferiami wladzy. Materialy konferencji zorganizowanej przez Zamek Królewski na Wawelu, Instytut Historii UJ, Instytut Historii Akademii Pedagogicznej w Krakowie, 2-5 kwietmia 2001, red. R. Skowron, Kraków 2001, s. $357-358$.

${ }^{13}$ W. Pałucki, Drogi $i$ bezdroża..., s. 149-151.

14 Ibidem, s. 203, 208, 214-217, 230.

15 Odnosi się to do: Michała Korybuta Wiśniowieckiego, Jana Sobieskiego, Stanisława Leszczyńskiego i Stanisława Augusta Poniatowskiego.

${ }^{16}$ VL, II, f. 1298: Rationes skarbu i stohu naszego; f. 1334: Rationes stolu Krola Iego Milości.

${ }^{17}$ A. Filipczak-K ocu r, Finanse..., s. 29.

${ }^{18} \mathrm{Z}$ siedmiu synów Zygmunta III Wazy, w dzieciństwie zmarło trzech, z pięciu córek przeżyła jedna. Z kolei Jan III Sobieski dochował się czterech synów i jednej córki, zaś z sześciu synów Augusta III Sasa czterech dożyło lat dojrzałych, z dziewięciu córek dwie zmarły w dzieciństwie. Stanisław August Poniatowski nie posiadał legalnego potomstwa, miał liczne rodzeństwo: trzech braci i dwie siostry. 
gającej żony stwarzało panującemu nie lada problem. Elekcyjny tron w Rzeczpospolitej nie dawal z zasady żadnej gwarancji, że któryś z potomków w linii meskiej uzyska tron po ojcu. Dlatego troska o bezpieczeństwo materialne królewiczów zmuszała władców do podejmowania rozmaitych działań, które miały jego najbliższym zapewnić środki utrzymania. Brak odpowiednich przepisów dawał monarsze spore możliwości legalnych działań, choć niekiedy nie wahał się on przed złamaniem obowiązujących zwyczajów i konstytucji. W ręku władcy znajdowała się gratia distributiva, shuząaca władcy do skutecznego rządzenia w państwie. Mógł on jednak wykorzystywać ją - co było nadużyciem - w interesie swoich krewnych ${ }^{19}$.

4.1. Członkowie familii królewskiej czerpali rozmaite materialne korzyści ze swojej pozycji rodzinnej. Oto źródła najważniejszych z nich, te najczęściej stosowane i przynoszące dochody:

- dobra ziemskie: wchodzące w skład oprawy królowej, włości przejmowane $w$ użytkowanie lub dzierżawę, wykupione $\mathrm{z}$ zastawu przez członków rodziny królewskiej królewszczyzny, zakupione na własność, pozyskane na drodze darowizny majętności należące dotąd do zasobu szlacheckiego, dobra uzyskane przez zapis sum od prywatnych właścicieli;

- urzędy i beneficja kościelne;

- pensje ${ }^{20}$.

4.2. A oto sposoby wykorzystane dla finansowania najbliższych monarchy.

4.2.1. Podstawowym źródłem dochodów społeczeństwa polskiego od czasów piastowskich były dobra ziemskie. Ale wykorzystywanie ich przez monarchę zaczęło wzbudzać zainteresowanie szlachty dopiero w XV w., od połowy którego domena ziemska zaczynała nabierać charakteru dóbr publicznych.

${ }^{19}$ Królowi Michałowi Korybutowi Wiśniowieckiemu opozycja zarzucała w 1672 r. rozdawnictwo dóbr krewnym, z kolei stronnicy monarchy twierdzili, że było tego niewiele. Zarzut odnosił się do dóbr Solec i Kamionka, zob. T. Korzon, Dola $i$ niedola Jana III Sobieskiego 1629-1674, t. III, Krakow 1898, s. 162, z odesłaniem do: Exorbitancyj w MS Ossol., nr 336, s. 195; A. Przy b ós, Michal Korybut Wiśniowiecki 1640-1673, Kraków-Wrocław 1984, s. 189. Nie znamy charakteru tych nadań.

${ }^{20}$ Nadania wysokich urzędów przynosity korzyści materialne nie tylko królowi, lecz i jego małżonce, jak i ich otoczeniu, zob. W. Czapliński, Sprzedawanie urzędów w Polsce $w$ polowie XVII wieku, PH 1959, t. L, z. 1, s. 53, 56-57; J. M a t u s ze w s ki, Sprzedawalność urzedów w Polsce, CPH 1964, t. XVI, z. 2, s. 149, 165; H. W is n e r, Rozdawnictwo i sprzedaż urzęów w czasach Zygmunta III, PH 1970, t. LXI, z. 1, s. 448-449. Innym przykładem są podarki, które król $\mathrm{i}$ jego bliscy otrzymywali od miast $\mathrm{w}$ zamian za potwierdzenie dotychczasowych przywilejów, E. Ciésłak, Przetargi Jana III Sobieskiego z Gdańskiem $o$ starostwo puckie, Rocznik Gdański 1962, t. XXI, s. 151. 
Ponieważ nie było norm prawa stanowionego zabraniających panującemu nabywania dóbr ziemskich, pojawiła się możliwość, że obok królewszczyzn o charakterze publicznym, w ręku królewskim znajdą się dobra stanowiące jego prywatny majątek. I chociaż opinia szlachecka uważała, że panujący nie mial do tego prawa, monarcha nie liczył się $\mathrm{z}$ tym stanowiskiem ${ }^{21}$. Królowie $z$ dynastii Wazów na tronie polskim, a w ślad za nimi następni władcy elekcyjni ${ }^{22}$, podejmowali różne zabiegi aby wejść w posiadanie dóbr, które dając mocne podstawy materialne rodzinie wzmocniłyby równocześnie jej stanowisko.

- Kupno dóbr. Konstancja, druga żona Zygmunta III, kupiła w 1624 r. dziedziczną majętność Mikolaja Komorowskiego - wielkie dobra żywieckie, które król i królowa traktowali jako prywatne. Kupno tych dóbr wywołało ostre protesty szlachty, która uznała transakcję za sprzeczną z prawem i obyczajami, domagając się uznania ich za królewszczyznę $e^{23}$. Szlachta $w$ transakcji tej upatrywała zamachu na wolności szlacheckie, obawiała się bowiem, iż dobra posłużą rodzinie królewskiej do stworzenia dziedzicznego majątku dającego niezależność finansową ${ }^{24}$. Obawy i sprzeciw szlachty $\mathrm{z}$ powodu zakupionych dóbr wyraził w $1625 \mathrm{r}$. A. Lisiecki, trafnie dostrzegając $w$ tym dążenie do umocnienia dynastii i dziedziczności tronu ${ }^{25}$.

Na sejmie $1626 \mathrm{r}$. szlachta $\mathrm{w}$ zasadzie pogodziła się z dokonanym zakupem, ale domagala się złożenia przez króla przyrzeczenia, iż tego typu sytuacje nie będą się powtarzać, a starostą dóbr żywieckich zostanie szlachcic polski - posesjonat, który będzie wypełniał wszystkie świadczenia na rzecz Rzeczypospolitej. Proszono monarchę o wyrażenie zgody na to, aby w sprzyjających okolicznościach starostwo zostało odkupione przez skarb państwa i włączone do wielkorządów krakowskich ${ }^{26}$. Król żądanego przez szlachtę przyrzeczenia

${ }^{21}$ Jaskrawym przykładem jest działalność Bony, która zmierzała do wyraźnego oddzielenia majątku królewskiego od własności publicznej.

${ }^{22}$ Posiadali oni dobra prywatne, z których dochody, po objęciu tronu nie przekształcały się w środki publiczne; dochody te mogły więc być wykorzystywane do powiększania majątności rodziny.

${ }^{23} \mathrm{~K}$. C hła p ows k i, Spór o kupno dóbr żywieckich przez królowq Konstancje w latach 1634-1631, KH 1997, R. CIV, z. 2, s. 8 z odesłaniem do: Rkp. Bibl. PAN Kórnik 338, k. 71-72; AGAD, Arch. Radziwiłłów VI-II, 49, k. 73-74; Arch. Publ. Potockich 31/II, k. 609-610, 640-641.

${ }^{24}$ Kronika Pawla Piaseckiego biskupa przemyślskiego, wyd. J. Bartoszewicz, Kraków 1870, s. $310-311$.

${ }^{25}$ Obrona wolności y praw Rzpltey Królestwa Polskiego: w którey z historyi, zwyczaiów, praw, statutów $i$ konstytucyi Królestwa, dostatecznie dowodzi sie, iż prześwietnemu domowi królewskiemu niewolno mieć żadnych dziedzicznych posiadlości w Królestwie polskiem $i W$. L. Litewskiem, K. Estreicher, Bibliografia polska, t. XXI. Kraków 1906, s. 332.

${ }^{26}$ J. Kwak, Sejm warszawski 1626 roku, Studia i Monografie [Opole] 1985, nr 103, s. 93 $z$ odesłaniem do: AGAD, AR VI, II-49, s. 120-121; B.K. nr 317, k. 326-327; nr 338, s. 117-118. 
nie złożył, lecz aby ją uspokoić, wyraził zgodę na wykup dóbr, za życia królowej lub po jej śmierci, za kwotę 600 tys. zł przez Rzeczpospolitą ${ }^{27}$. Dobra te miały wejść w skład królewszczyzn.

Podobnie, zgodnie ze swoimi planami, potrafił Zygmunt III rozwiązać sprawę majętności Nieporęt ${ }^{28}$. Prażmowscy nabyli Nieporęt w $1480 \mathrm{r}$. od księcia mazowieckiego Bolesława. Linia potomków wywodząca się od nabywcy Nieporętu wygasla w 1560 r.; wówczas przeszedł on w ręce Korony ${ }^{29}$. W okresie egzekucyjnym, w czasie rewizji listów (1564 r.), dawna posiadłość Prażmowskich uznana została przez rewizorów za własność królewską. $Z$ tym nie pogodzili się pozostali przedstawiciele rodu i zglaszali ustawicznie pretensje ${ }^{30}$. Ostatecznie dobra te, bez zgody stanów, znalazły się w dziedzicznym posiadaniu dzieci króla $^{31}$. W. Pałucki wysunął przypuszczenie, iż miało to związek z konstytucją sejmu 1632 r. Opatrzenie Najaśniejszego Potomstwa naszego ${ }^{32}$. W 1642 r. królewna Anna Katarzyna, wychodząc za mąż, odstąpiła część swego dziedzictwa w Nieporęcie, którą posiadała post Serenisimos olim Parentes suos, bratu swemu Janowi Kazimierzowi ${ }^{33}$, który ustępując $\mathrm{z}$ tronu, w $1668 \mathrm{r}$. podarowal dobra Jezuitom ${ }^{34}$.

W 1654 r. królowa Maria Ludwika, mając w dożywotnim posiadaniu starostwo kamieńczykowskie (na Mazowszu), zwróciła się do sejmu o zgodę na jego kupno, z zamiarem uposażenia zgromadzenia sióstr wizytek, które sprowadziła z Francji ${ }^{35}$. Spotkało się to ze sprzeciwem szlachty, niemniej sejm uchwalił konstytucję ${ }^{36}$, dzięki czemu królowa nabyła własność dóbr za

${ }^{27}$ Ibidem, s. 95 z odesłaniem do: AGAD, AR VI, II-49, s. 126; B.K. 317, k. 330; B.U.Wr. Zb. Steinwehra, fol. 37, t. II, s. 323.

${ }^{28}$ W. P a lu cki, Przynależność wlasnościowa osiedli, [w:] Atlas historyczny Polski. Mazowsze $w$ drugiej polowie XVI wieku, red. W. Pałucki, cz. II: komentarze, indeksy, Warszawa 1973, s. 90 , przyp. 11.

${ }^{29}$ Rodzina, herbarz szlachty polskiej, oprac. S. hr. Uruski przy współudziale A. A. Kosińskiego, uzupeł. A. Włodarski, t. XIV, Warszawa 1917, s. 328.

30 Dyaryusze sejmowe r. 1597..., wyd. dr E. Berwiński, Kraków 1907, Scriptore renum Polonicarum [SRP, XX], s. 359, 361-362.

${ }^{31}$ W. P a łu cki, Drogi $i$ bezdroża..., s. 201, przyp. 310.

${ }^{32}$ W. P ału cki, Przynależność wlasnościowa..., s. 90, przyp. 11. O konstytucji zob. s. 319.

${ }^{33}$ Cyt. za W. Pałucki, (ibidem, s. 90, przyp. z odesłaniem do MK, 186, f. 136).

${ }^{34}$ Slownik Geograficzny Królestwa Polskiego, t. VIII, s. 107, s.v. Nieporęt (autor Br. Chlebowski); S. Załęski, Jezuici $w$ Polsce, t. IV, cz. II: Kolegia $i$ domy zalożone $w$ pierwszej dobie rzqdów Zygmunta III 1588-1608, Kraków 1904, s. 855, przyp. 2. Szlachta była przeciwna temu, aby abdykujacy monarcha zatrzymywał swoje dobra prywatne, zob. W. K ła c zew ski, Abdykacja Jana Kazimierza. Spoleczeństwo szlacheckie wobec kryzysu politycznego lat 1667-1668, Lublin 1993, s. 164, z odesłaniem do Akta ziemi kujawskiej, t. II, s. 211-218.

${ }^{35}$ VL, IV, f. 452 - Fundacya Panien Zakonnych od Nayiaśnieyszey Malżonki naszey Krolowy Ieymci Ludowiki Maryi; Slownik Geograficzny Królestwa Polskiego, t. III, s. 742, s.v. Kamienczyk (autor Al. Krył, Br. Chlebowski); K. Chła powski, Alienacja dóbr królewskich w latach 1578-1668, PH 1979, t. LXIX, z. 4, s. 657.

${ }^{36}$ K. Chła pow ski, Alienacja dóbr..., s. 657. 
kwote 130 tys. zł., które była jej dłużna Rzeczpospolita. Był to - jak ustalił K. Chłapowski - jedyny w latach $1578-1668$ przypadek sprzedaży zgodnie $\mathrm{z}$ prawem. Przekazanie starostwa siostrom nastąpiło w 1663 r. Dochody $\mathrm{z}$ niego szacowano na 22 tys. zł rocznie ${ }^{37}$.

Dobra ziemskie kupował również Jan III Sobieski. W 1677 r. nabył za kwotę 43 tys. zl. dobra Milanów na południe od Warszawy ${ }^{38}$, i aby ominąc obowiązujące przepisy zabraniające kupowania majątków ziemskich, Sobieski skorzystał z pośrednictwa jednego ze swoich przyjaciól - wielkiego koniuszego koronnego Marka Matczyńskiego. Po oblatowaniu dokumentu w księgach Metryki Koronnej dobra zostały przekazane królowi. Król nabyl wówczas także dobra Powsinek składające się z trzech wsi i dwóch folwarków, które zostały włączone do klucza wilanowskiego ${ }^{39}$. Na sejmie 1683 r. Krzysztof Grzymultowski wytknął tę transakcję królowi ${ }^{40}$. Nie wywołało to żadnej zmiany w postępowaniu władcy; zakupił on część dóbr Pólkowa na północ od Warszawy, które na cześć żony nazwano Marymontem ${ }^{41}$. Sprawa ta została podniesiona po śmierci króla przez szlachtę $w$ instrukcjach sejmikowych w $1696 \mathrm{r}^{42}$

August II Sas kupil od Konstantego Sobieskiego pałac Morsztynowski w Warszawie oraz pałac Marymont z przyległościami ${ }^{43}$.

Stanislaw August Poniatowski nabył w 1766 r. Jazdów Stary od księcia Kaspra Lubomirskiego, urządziwszy sobie rezydencję w Łazienkach. Okazały pałac ujazdowski z placem w 1784 r. podarował król miastu ${ }^{44}$.

${ }^{37}$ Loc. cit.

${ }^{38}$ M. Drozdowski, A. Z a h o r s k i, Historia Warszawy, Warszawa 1972, s. 79; Z. Wój ci k, Jan Sobieski 1629-1696, Warszawa 1983, s. 393. J. S ta r z yń ski, Wilanów. Dzieje budowy palacu Jana III, [w:] Studja do dziejów sztuki w Polsce, t. V, Varsoviana 2, Warszawa 1933, s. 3, z odesłaniem do: AGAD, MK 211, s. 80=83; A. Gr. warsz. Obligacye 28, k. $540 / \mathrm{V}$.

${ }^{39}$ Slownik Geograficzny Królestwa Polskiego, t. VII, s. 896, s.v. Powsin (autor Br. Chlebowski).

${ }^{40}$ Mówca odwołal siẹ do konstytucji z $1631 \mathrm{r} .:$ Ażeby juri terrestri in persona subsit, jako sq formalia prawa, albo dóbr ziemskich nabywać nie może. [...] Wilanów prawda, że sztuka piasku, ale $i$ na tym piasku siedzialby szlachcic, $i$ na Powsinku drugi. Zob. Krzysztofa Grzymultowskiego, wojewody poznańskiego listy i mowy, wyd. A. Jabłonowski, Warszawa 1876, s. 112 [Źródła Dziejowe, t. I].

${ }^{41}$ M. Drozdowski, A. Zahorski, Historia Warszawy, s. 80; Z. W ójci k, Jan Sobiecki..,, s. 392 .

${ }^{42}$ Szlachta dobrzyńska w instrukcji wręczonej posłom na sejm konwokacyjny 1696 r. domagała się m.in., aby dobra ziemskie zakupione przez króla Jana III zostały uznane za dobra koronne i rozdane osobom zasłużonym. Żądanie to nie obejmowało dóbr wilanowskich, Lauda sejmikowe ziemi dobrzyńskiej, wyd. F. Kluczycki, Kraków 1887, s. 167, nr 75 §; zob. również: AGZ, t. 22, cz. III: Lauda wiszeńskie 1673-1732, wyd. A. Prochaska, Lwów 1914 , s. 281, nr 99, § 18; Akta sejmikowe województwa krakowskiego, t. V: 1681-1696, wyd.

A. Przyboś, Wrocław-Warszawa-Kraków-Gdańsk-Lódź 1984, nr 65, s. 182, pkt 32.

${ }^{43}$ A. K r ól, Marymont. Dzieje letniej rezydencji Jana Sobieskiego, Augusta II i III oraz Instytutu Agronomicznego, Rocznik Warszawski 1960, t. I, s. 41.

${ }^{44}$ Slownik Geograficzny Królestwa Polskiego, t. XII, s. 766, s.v. Ujazdów (autor Br. Chlebowski). 
Bratanek króla, książę Stanisław, syn Kazimierza Poniatowskiego, nabył w 1780 r. od Kaspra Rogalińskiego starostwo korsuńskie, zaś w 1785 r. od Michała Wielhorskiego dobra Horochów na Wolyniu ${ }^{45}$.

- Zastawnicy z rodziny królewskiej. Po śmierci Zofii Działyńskiej (wdowy po staroście Łukaszu Działyńskim), w 1604 r. król nadal swej młodszej siostrze Annie Wazównie prawo wykupu starostwa brodnickiego ${ }^{46}$. Siostra Zygmunta III spłaciła z sumy zastawnej spadkobierców Zofii Działyńskiej ${ }^{47}$. Starostwo dzierżyła aż do śmierci (1625 r.). Dobra królewskie oddane w zastaw pozostawały długi czas w ręku zastawników, dopóki król nie spłacił długu. Zastawnik uzyskiwał prawa i dochody niemal właściciela, ograniczony był jedynie w swobodzie alienacji na rzecz osób trzecich. Dobra zastawne mogły być dziedziczone. $\mathrm{Z}$ kolei $\mathrm{w} 1611 \mathrm{r}$. starostwo golubskie będące $\mathrm{w}$ zastawie w ręku rodziny Kostków, po śmierci Jerzego Kostki zostało nadane przez Zygmunta III Annie Wazównie ${ }^{48}$. Nie wiemy, czy królewna spłacila spadkobierców dotychczasowego zastawnika.

Królowa Konstancja - żona Zygmunta III, wykupiła za własne pieniądze folwark Oniszki zastawiony przez króla u Radziwiłłów, który wchodził w skład dzierżawy Olitckiej w Wielkim Księstwie Litewskim należącej do dóbr oprawnych $^{49}$. Wykupienie spowodowało wygaśnięcie stosunku zastawnego między monarchą a dotychczasowym zastawnikiem i przywrócenie go do dóbr oprawnych.

W 1678 r. Jan III Sobieski wykupil za kwotę 120 tys. guldenów zastawione Gdańszczanom starostwo puckie ${ }^{50}$.

W tym samym roku Andrzej Gembicki, trzymający tytułem zastawu za 200 tys. guldenów starostwo nowodworskie, uzyskal pozwolenie od sejmu grodzieńskiego na jego cesję królowi i jego potomstwu albo innej osobie stanu szlacheckiego z Królestwa Polskiego i Wielkiego Księstwa Litewskiego, która wykupi starostwo za wyżej wymienioną sumę ${ }^{51}$. Władca nie był osobą prywatną; był zawsze osobą publiczną, dlatego potrzebna była zgoda sejmu,

${ }^{45}$ PSB, 27, s. 482, s.v. Poniatowski Stanislaw (autor J. Michalski); Slownik Geograficzny Królestwa Polskiego, t. V, s. 44, s.v. Korsuń (autor E. Rulikowski). Starostwo to składało się z 27 wsi i przynosiło dochód 129150 złp. 12 gr.

${ }^{46}$ PSB, t. I, red. W. Konopczyński, Kraków 1932, s. 134, s.v. Anna Wazówna (autor: K. Le p s z y). Zob. też ks. P. Cza plew sk i, Senatorowie świeccy, podskarbiowie i starostowie Prus Królewskich 1454-1772, Roczn. Tow. Nauk. w Toruniu 1921, XXVI-XXVIII (1919-1921), s. 64-65.

${ }^{47}$ Dr. H. Plehn, Geschichte des Kreises Strasburg in Westpreussen, Lepzig 1900, s. 124, z odestaniem do: MK, bd. 148, s. 350; bd. 149, s. 405.

${ }^{48}$ PSB, I, s. 134.

${ }^{49} \mathrm{VL}, \mathrm{III}, 306$, warunek summy dziesięciu tysięcy zlotych na Oniszkach.

${ }^{50}$ Ks. P. Cz a plew ski, Senatorowie świeccy..., s. 163, 164.

${ }^{51}$ VL, V, f. 564, Consens Ur. Staroście Nowodworskiemu; P. Cza plewski, Senatorowie świeccy..., s. 148, za nim S. Ci a ra, Sprzedaż urzędów i królewszczyzn $w$ drugiej polowie XVII w., [w:] Wladza i spoleczeństwo w XVI i XVII w. Prace ofiarowane Antoniemu Maczakowi w sześćdziesiąta rocznice urodzin, Warszawa 1989 , s. 84. 
aby król stał się wierzycielem Rzeczypospolitej. Przyszłemu nabywcy zezwalano trzymać starostwo do czasu rzeczywistego wykupu jego przez Rzeczpospolitą. Monarcha wykupil starostwo z zastawu w $1680 \mathrm{r}^{52}$ i pozostało ono w ręku jego rodziny aż do roku $1737^{53}$.

- Darowizny dóbr ziemskich. W źródłach natrafiamy na pojedyncze informacje o zapisach majątkowych poczynionych przez prywatne osoby na rzecz rodziny królewskiej ${ }^{54}$. W 1682 r. Stanisław Koniecpolski, umierając bezdzietnie, zapisał Brody z kluczem oraz Podhorce synowi króla Jana III - Jakubowi ${ }^{55}$. Temu zapisowi jako naruszającemu postanowienia konstytucji z $1631 \mathrm{r}^{56}$ sprzeciwiała się szlachta $^{57}$.

Starania o zapewnienie dochodów materialnych na utrzymanie rodziny nie ograniczały się tylko do nabywania dóbr czy nadań dochodów ze starostw. Natrafiamy na wzmianki o innych źródłach finansowania.

- Nadania w użytkowanie. Królowa Anna otrzymała w 1593 r. od Zygmunta III nadanie w użytkowanie (in usum fructum) wsi Lętkowice w powiecie proszowickim, po śmierci dotychczasowego posiadacza Jana Wielopolskiego ${ }^{58}$.

52 Jan Kazimierz, zastawiając w 1654 r. za zgodą sejmu na potrzeby Rzeczpospolitej tenute nowodworską, z tytułu utraconych dochodów królewskich miał otrzymywać rocznie ze skarbu 20 tys. zl.; ks. P. Czaplewski, Senatorowie świeccy..., s. 148. Jan III Sobieski od 1687 r. uzyskiwał $\mathrm{z}$ tego tytułu 17 tys. zł rocznie, bowiem w zamian za niezrealizowane dochody wyznaczono mu jako uposażenie starostwo kozienickie; R. R ybarski, Skarb $i$ pieniadz za Jana Kazimierza, Michala Korybuta i Jana III, Warszawa 1939, s. 481.

${ }^{53}$ Ks. P. Czaplewski, Senatorowie świeccy..., s. 148-149, z odesłaniem do: Lengnich VIII, 181, 183.

${ }^{54}$ Konstytucja z 1510 r. De testamentis condendis, zakazując dokonywania zapisów testamentem zarówno đóbr dziedzicznych, jak i zastawnych na rzecz kościoła, zezwalała czynić je na rzecz króla. Nie wspominała jednak o zapisach na rzecz potomstwa monarchy, VL, I, 369.

${ }^{55} \mathrm{X}$. S a d ok B a rąc z, Wolne Miasto Handlowe Brody, Lwów 1865, s. 57-61; L. T a to m ir, Slady króla Jana III w kraju naszym..., Lwów 1883, s. 29-30, 83; Slownik Geograficzny Królestwa Polskiego, t. VIII, s. 395, s.v. Podhorce (autor Lu. Dz. = Ludwik Dziedzicki). Nie był to zapis bezinteresowny. Stanisław Koniecpolski w zamian za zapisanie Jakubowi Sobieskiemu Brodów i Podhorców otrzymał kasztelanię krakowską. Zob. X. S a d ok B a r ą cz, Wolne Miasto..., s. 57; PSB, t. XIII, s. 528, s.v. Koniecpolski Stanislaw h. Pobóg (autor A. Pr zy bo ś); S. Ci a r a, Sprzedaż urzedów..., s. 229, z odesłaniem do: Pamiętniki Koniecpolskich, wyd. S. Przyłęcki, Lwów 1842, s. 182.

${ }^{56}$ Konstytucja $O$ dobrach ziemskich dziedzicznych zakazywała nabywania ziemskich dóbr dziedzicznych członkom rodziny królewskiej nec modo donationis, nec emptionis, albo hipotecae, neque quovis obligationis modo, aut aliquo alio jure, VL, III, f. 666.

${ }^{57}$ Świadczy o tym wypowiedź wojewody poznańskiego na sejmie 1683 r.: Co sie zas tknie Brodów $i$ Podhorec, nie może slużyć donacya królewiczowi Jmci, i zle to suppositum, żeby o tem prawa nie bylo. Przeczytać tylko konstytucjcye anni 1631, która piszqc to immediate czytalem: każdego informabit, że jest wlasnie na potomstwo królewskie [...] JMć podlegal aequalitati juris et poenae. Ażeby juri terrestri in persona subsit jako sq formalia prawa, albo dóbr ziemskich nabywać nie może, zob. Krzysztofa Grzymultowskiego, wojewody poznańskiego listy $i$ mowy, LIX, s. 112.

${ }^{58}$ W. P a łu ck i, Drogi $i$ bezdroża..., s. 193 z odesłaniem do MK, 139, f. 55. 
Na sejmie warszawskim 1620 r. stany koronne i litewskie wyraziły zgodę na oddanie królewiczowi Władysławowi w administracje i użytkowanie ziem zdobytych w wyniku dymitriad ${ }^{59}$. Dochody z nich szły - jak przedstawiał królewicz w liście z 11 XII 1622 r. do Krzysztofa Radziwiłła, hetmana polnego litewskiego - na utrzymanie załóg zamkowych i naprawę fortyfikacji, a $w$ konsekwencji sam nie uzyskiwał żadnych dochodów ${ }^{60}$.

- Dzierżawa dóbr. W latach 1633-1647 królewicz Karol Ferdynand, biskup wrocławski, dzierżawił Ujazdów - najbogatszy folwark w starostwie warszawskim. Z tego tytułu, prócz kwarty do Rawy, płacił królowi 700 zł rocznie ${ }^{61}$.

Bratanek króla Stanisław Poniatowski - syn Kazimierza, uzyskał od Izabeli Branickej - siostry króla, cesję na starostwo bielskie i leśnictwo bielskie, na których zachowywala ona dożywocie (zmarła w 1808 r.). W latach 1789-1796 Poniatowski - jak stwierdził J. Michalski - dzierżawił wymienione królewszczyzny od Branickiej początkowo za 9 tys. dukatów rocznie, później za nieco większą kwotę ${ }^{62}$. W tym samym czasie wydzierżawił od Michała Wielhorskiego starostwo kamienieckie w woj. brzeskim litewskim. W 1783 r. został on generalnym dzierżawcą królewskich ekonomii litewskich.

- Dobra oprawne ${ }^{63}$. Wnoszony na mocy kontraktu małżeńskiego posag królewskiej małżonki był zabezpieczony przez specjalną sejmową konstytucję na wyliczonych starostwach. Królewszczyzny te winny wracać do skarbu po ustaniu małżeństwa i po rozliczeniu $\mathrm{z}$ wdową lub rodziną zmarlej królowej ${ }^{64}$. Niejednokrotnie - jak zauważa W. Pałucki - przyznawane jako oprawa dobra znajdowały się na podstawie różnych tytułów w rękach prywatnych. W rezultacie królowa nie otrzymywala z nich zapisanych dochodów. Dopiero po śmierci starosty, względnie wygaśnięciu umowy dzierżawnej bądź cesji, wchodzila ona $\mathrm{w}$ ich użytkowanie. Różnicę $\mathrm{w}$ dochodach między zapisaną sumą oprawy a uzyskiwanymi przez królową uzupelniał król z własnych dochodów (z żup, dochodów celnych) ${ }^{65}$. Prawo do dochodów z dóbr oprawnych

${ }^{59}$ Ordynacya Prowincyi od Moskwy rekuperowanych, VL, III, f. 368-371.

${ }^{60}$... ta administracya zamków Siewierskich od Jeo Kro. Mci i Rzptej nam pozwolona, żadnego nam dotq̨d nie uczynila pożytku, gdyż wszystkę intratę na praesidia tameczne $i$ na poprawe $i$ budowanie zamków obracamy, co ukazać Rzptej gotowiśmy, $k$ że zatrzymaniem onych żadnego nieodnieślismy pożytku...; zob. Listy Wladyslawa IV do Krzysztofa Radziwilla hetmana polnego W. X. Litewskiego pisane 1612-1632, ogłosił A. Muchlinski, Kraków 1867, nr XXIV s. 45-46.

${ }^{61}$ W. Pału cki, Drogi $i$ bezdroża..., s. 194, z odesłaniem do: Rach. Król., 349, f. 249, 327, $313,327$.

${ }^{62}$ PSB, t. $27 / 3$, s. 482, s.v. Poniatowski Stanislaw h. Ciolek (autor J. Michalski).

${ }^{63}$ Problem oprawy królowej wymaga osobnego opracowania.

${ }^{64}$ P. Dąbkowski, Prawo prywatne polskie, t. I, Lwów 1910, s. 447.

${ }^{65}$ VL, II, f. 1666 Oprawa Krolowey IeyMci Konstancyi. Zdaniem W. Pałuckiego, król, wypłacając różnicę w dochodach między zapisaną sumą oprawną a uzyskiwanymi dochodami, mógł ją odebrać po śmierci tenutariusza $z$ dóbr oprawnych, W. P ału ck i, Drogi i bezdroża..., s. 166. Pogląd ten nie znajduje potwierdzenia w źródłach. 
po śmierci matki przypadało jej potomstwu. Po śmierci matki ojciec musial wydać je jej dzieciom; dopóki zaś dzieci nie osiągnęły lat sprawnych, a ojciec nie zawarł powtórnie związku małżeńskiego, on użytkowal te dobra ${ }^{66}$. Zygmunt III, po śmierci swej pierwszej żony Anny Austriaczki (zm. 1598 r.), przepisał jej dobra oprawne na królewicza Wladysława, co spotkało się z protestami ze strony szlachty na sejmach 1605 i $1606 \mathrm{r}$. W pozostawieniu dóbr oprawnych w ręku królewicza upatrywal sejmik województwa bełskiego zagrożenie w utrzymaniu jedności dóbr Rzeczypospolitej. Postulowano, aby znosząc oprawę, spadkobierce splacić wyjątkowo dochodami z kwarty ${ }^{67}$. $\mathrm{W}$ propozycjach uchwal podanych od sejmiku bełskiego na sejmie $1605 \mathrm{r}$. opowiedziano się ostatecznie, aby posag zostal spłacony $z$ poboró $w^{68}$.

Zygmunt III, oddając w 1604 r. w trzyletnią dzierżawę starostwo bielskie należące do oprawy królowej Anny Austriaczki, nalożył na dzierżawcę obowiązek placenia królewiczowi Władysławowi kwoty $8500 \mathrm{zl}$ rocznie ${ }^{69}$. Po śmierci drugiej żony królowej Konstancji (zm. 1631 r.), Zygmunt III w uniwersałach rozeslanych na sejmiki przedsejmowe żądał naznaczenia królewiczom dochodów z dóbr oprawnych po zmarłej królowej ${ }^{70}$. W rezultacie potomstwo króla otrzymało prawo rezydencji i do pobierania dochodów w części dóbr należących do oprawy ${ }^{71}$.

Władysław IV po śmierci swej małżonki Cecylii Renaty (zm. 1644 r.) nosił się z zamiarem przeznaczenia jej oprawy na uposażenie ich syna, dlatego starostw stanowiących oprawe zmarłej nie rozdał w ustawowym

${ }^{66}$ P. Dąbkowski, Prawo prywatne..., t. I, s. 435,437

${ }^{67}$ Co się dotyczy posagu samego, z kwarty co najprędzej niech będzie odlożon królewiczowi JM a dobra Rzpltej żeby byly wolne, przez bojaźn na potem dla dismembracyi i zatrudnienia ztąd $i$ mieszaniny; zob. Instrukcyja Województwa Belskiego, poslom na sejm warszawski w roku 1605 przez Jego Mci Pana Zamojskiego Kanclerza i hetmana pisana, [w:] A. S ok ołow sk i, Przed rokoszem. Studyjum historyczne za czasów Zygmunta III, [w:] Rozprawy i sprawozdania $z$ posiedzeń Wydzialu Historyczno-Filozoficznego AU, t. XV, Kraków 1882, s. 208-209 z odesłaniem do: rkps. Bibl. Ks. Czartor., nr 341, fol. 4; A. Strzelecki, Sejm z roku 1605, Kraków 1921, s. 55, 140, 165; sprawę oprawy zmarłej królowej poruszano na sejmie 1606 r., zob. W. S o b ie sk i, Pamiętny sejm (1606), Warszawa-Lublin-Lódz-Kraków 1913, s. 104, 131, przyp. 1 .

68 Artykuly Belskie podane na Sejmie Warszawskim 1605, [w:] A. S o k o lo w s k i, Przed rokoszem..., s. 218. Zniesienie oprawy, z odesłaniem do rkps bibl. Ks. Czartor., nr 2729, fol. 4.

${ }^{69}$ W. Pału cki, Drogi i bezdroża..., s. 187, z odesłaniem do MK 148, f. 309.

${ }^{70}$ Pozytywnie do żądania królewskiego ustosunkowała się szlachta zgromadzona na sejmiku województw poznańskiego i kaliskiego w Srodzie (19 II 1632 r.) i szlachta ruska na sejmiku w Wiszni (20 II 1632 r.), zob. Akta sejmikowe województw poznańskiego i kaliskiego, t. I, cz. 2, s. 328-329; AGZ, t. XX, nr 172, s. 306-307. O zamiarach podzielenia oprawy po zmarłej królowej miẹdzy królewiczów Jana Kazimierza, Aleksandra i królewnę Annę Katarzynę zob. list ks. Jana Wężyka - arcybiskupa gnieznieńskiego z 19 II 1632 r. na sejmik przedsejmowy województw poznańskiego i kaliskiego w Srodzie, Akta sejmikowe województw poznańskiego i kaliskiego, t. I, cz. 2, wyd. W. Dworzaczek, Poznań 1958, s. 327, nr 344.

7 Zob. s. 319. 
czasie. $\mathrm{Z}$ żądaniem takim wystąpil, za pośrednictwem senatorów, na sejmie $1645 \mathrm{r}^{72}$, jednak nie uzyskał na to zgody ${ }^{73}$.

Nie stwierdziliśmy natomiast, by następni monarchowie elekcyjni wykorzystywali dobra oprawne jako źródło utrzymania swego potomstwa.

- Starostwa jako uposażenie. Monarsze przysługiwało prawo nadawania starostw oraz uposażeń z nimi związanych. W przywileju koszyckim postanowiono, iż od wykonywania starościńskich funkcji wyłączeni są członkowie rodzin panujących ${ }^{74}$; nie mogli oni objąć urzędu. Dochody z tenuty starościńskiej w zależności od tytułu prawnego dzierżenia starostwa pobierał w całości aktualny starosta, albo część $\mathrm{z}$ nich przypadała panującemu ${ }^{75}$. Od czasów panowania Zygmunta III źródła potwierdzają nadania dochodów $\mathrm{z}$ tenuty $\mathrm{z}$ niektórych starostw jako uposażenia na rzecz członków rodziny królewskiej.

Po śmierci królewny Anny w 1625 r. dochody ze starostw brodnickiego i golubskiego nadał król w dożywocie swojej żonie Konstancji. Nadanie spotkało się z protestami ze strony szlachty, która uważała decyzję królewską za złamanie prawa ${ }^{76}$. Domagała się ona włączenia starostw do królewszczyzn, jako chleb dla zashużonych ${ }^{77}$. Odpowiadający na zarzuty posłów podkanclerzy koronny biskup S. Lubieński argumentowal, iż nie ma przepisu zabraniającego królowi nadawania dóbr małżonce, poza tym monarcha może nadawać dobra, komu chce. Poszczególni szlachcice również dają swym żonom dożywocia, czemuby $i$ król nie mógl tego uczynic ${ }^{78}$.

W 1609 r. królowa Konstancja otrzymała prawo do starostwa tucholskiego jako oprawnego ${ }^{79}$. W 1611 r. weszła w jego posiadanie. Kanclerz wielki

${ }^{72}$ A. Kerste n, Hieronim Radziejowski. Studium wladzy i opozycji, Warszawa 1988, s. 81-82. Występujacy w imieniu króla Hieronim Radziejowski, usiłując przeforsować żądanie monarsze, argumentowal: Zaslużyla na to dobrze świętobliwej pamięci królowa; cyt. za ibidem, s. 82.

73 J. Dzię gi elewsk i, Izba poselska w systemie wladzy Rzeczypospolitej czasów Wladyslawa $I V$, Warszawa 1990, s. 76.

${ }^{74}$ B. W ald o, Urzqd starosty sqdowego w Malopolsce w $X V$ i XVI wieku, Acta Univ. Lodz. 1985 , s. 115, 116. Autorka stwierdza zarazem, że wraz z ugruntowaniem się władzy Jagiellonów w Królestwie warunki zamieszezone w przywileju koszyckim i jego potwierdzeniach tracą aktualność.

${ }^{75}$ Ibidem, s. $188-189$.

${ }^{76}$ Kronika Pawla Piaseckiego..., s. 321.

77 J. K wak, Sejm warszawski..., s. 44.

${ }^{78}$ Cyt. za ibidem, s. 99.

79 Slownik Geograficzny Królestwa Polskiego, t. XII, s. 590, s.v. Tuchola (autor ks. Romuald Frydrychowicz). Dochód z Tucholi, według lustracji z 1602 r., oszacowano na 14390 zk; W. P ału ck i, Drogi $i$ bezdroża..., s. 189, z odesłaniem ASK, LIV, nr 18, f. 17v. Starostwo tucholskie było na drugim miejscu po człuchowskim w województwie pomorskim pod względem dochodowości; S. Ci a ra, Senatorowie $i$ dygnitarze koronni $w$ drugiej polowie XVII wieku, Wrocław-Warszawa-Kraków 1990, s. 84-85. 
litewski Albrycht S. Radziwiłl, trzymając je od 1622 r. tytułem do wiernych rakk, oddawal dochody królowej aż do jej śmierci $(1631 \text { r. })^{80}$. W 1629 r. kanclerz zapłacil królowej 12465 złp. oplaty rocznej ${ }^{81}$.

Wladyslaw - pierwszy syn Zygmunta III, uzyskuje od ojca starostwo międzyłęskie i osieckie w 1621 r., które za jego zgodą wydzierżawił w 1627 r. na okres ośmiu lat Jakóbowi Jacobsonowi - generalnemu administratorowi mennicy ${ }^{82}$. Wpływy na pokrycie potrzeb królewicza byly niewystarczające, w związku z czym podjął on starania o opatrzenie stosowne do swego stanu w $1622 \mathrm{r}^{83}$ Senatorzy, do których się zwrócil, radzili, by poczekał z tym do sejmu. Władysław poprzestał na prywatnych zabiegach u wpływowych osób $^{84}$. Ostatecznie w 1623 r. królewicz od ojca uzyskal, bez zgody sejmu, starostwo jaworowskie ${ }^{85}$.

W grudniu 1625 r. królewicz zwrócił się do sejmików z listem, prosząc o zwiększenie uposażenia ${ }^{86}$. Wysłał równiez list do Krzysztofa II Radziwilła oraz do kasztelana mińskiego Aleksandra Słuszki z prośbą o poparcie jego wniosku na sejmikach ${ }^{87}$. Stanowisko sejmików było w zasadzie przychylne, choć niektóre $\mathrm{z}$ nich odłożyły sprawę celem zasięgnięcia opinii innych sejmików. $\mathrm{Na}$ sejmie warszawskim $1626 \mathrm{r}$. w tej sprawie zwrócił się do izby poselskiej senat. Z kolei marszalek izby poselskiej Jakub Sobieski wystąpil wobec monarchy $\mathrm{z}$ wnioskiem, by ten nagrodzil najstarszego syna ${ }^{88}$. Wspomniany sejm uchwalił konstytucję Auctia prowizyi stolu Krolewica I. Mści Wladyslawa. Upoważniła ona monarchę do nadania królewiczowi starostw w Rzeczpo-

${ }^{80}$ Uzyskał je w 1622 r., zob. W. Pału cki, Drogi i bezdroża..., s. 189, z odesłaniem A. S. $\mathrm{R}$ adziwił1, Memoriale rerum gestarum in Polonia 1632-1656, t. III: 1640-1647, opr. A. Przyboś i R. Żelewski, Wrocław 1972, s. 100.

${ }^{81}$ W. P a łu ck i, Drogi i bezdroża..., s. 189, z odesłaniem AGAD, mikrofilm rpisu Riksarkivet, Sztokholm, Extranea 75, IX Polen, szpula 57.

${ }^{82}$ Ks. P. Cza ple wski, Senatorowie świeccy..., s. 137.

${ }^{83}$ Królewicz uskarżał się, iż ma tylko 50 tys. złp. dochodu, które otrzymywal od ojca.

${ }^{84} \mathrm{~J}$. Pietrzak, W przygaszonym blasku wiktorii chocimskiej. Sejm w 1623 r., Acta Univ. Wratisl. 1987, No 890, Historia LVII, s. 46, z odesłaniem do: Władysław Zygmunt do K. Radziwilła 11 XII 1622, Listy Wladyslawa IV do Krzysztofa Radziwilla [...] pisane 1612-1632, s. 45 .

${ }^{85}$ W. P a łu cki, Drogi i bezdroża..., s. 199, z odesłaniem do: MK, 169, f. 731-732.

${ }^{86} \mathrm{~J}$. K wak, Sejm warszawski..., s. 54, z odesłaniem: Lancelotti do Barberiniego 20 I 1626 r. z Warszawy, T. Rz., nr 8401, s. 212; Akta sejmikowe województwa poznańskiego i kaliskiego, t. I, cz. 2, nr 283, s. 200, pkt 4: Instrukcja poslom sejmowym z sejmiku przedsejmowego [...] w Srodzie 21 grudnia 1625 r. Zob. również, ibidem, nr 280, s. 196: List królewicza Wladyslawa do sejmiku przedsejmowego [...] $w$ Środzie 16 grudnia 1625 r., z Golubia 25 listopada $1625 \mathrm{r}$.

${ }^{87}$ J. K wak, Sejm warszawski..., s. 50 z odesłaniem: Królewicz Władysław do K. Radziwiłła z Golubia 23 XI 1625, AGAD, AZ nr 2886; tenże do A. Słuszki z Golubia 27 XI 1625, AGAD, AR II, nr 930; Listy Wladyslawa IV do Krzysztofa Radziwilla 1612-1632..., s. 66-67.

${ }^{88} \mathrm{H}$. W is ne r, Wladyslaw IV Waza, Wrocław-Warszawa-Kraków 1995, s. 45, z odesłaniem: Czart. rkps 1669 s. 35: Prośba za Królewiczem Wladyslawem imieniem izby poselskiej przez pana marszalka..., 1625. 
spolitej, ale dochód z nich nie mógł przekroczyć kwoty 50 tys. zł. Przyznane uposażenie miało równomiernie obciążać Wielkopolskę, Małopolskę i Wielkie Księstwo Litewskie ${ }^{89}$. Efektem uchwalenia konstytucji było nadanie w $1627 \mathrm{r}$. Władysławowi starostwa hrubieszowskiego $0^{90}$ i soleckiego, a w $1630 \mathrm{r}$. - krzepickiego ${ }^{91}$ w Koronie, borysowskiego i mereckiego w Wielkim Księstwie Litewskim, co się spotkało ze sprzeciwem szlachty ${ }^{92}$.

Wiosną 1632 r., na ostatnim za życia Zygmunta III sejmie, podjęto decyzję odnośnie do finansowego zabezpieczenia dzieci króla $\mathrm{z}$ drugiego małżeństwa, mianowicie Jana Kazimierza, Karola Ferdynanda i Anny Katarzyny ${ }^{93}$. Nastąpiło wówczas zalegalizowanie kwestionowanych dotychczas przez sejm nadań i nabytków, które wcześniej uzyskała królowa. W konstytucji podkréslono, iz za zgodą sejmu, tylko na ten jeden raz, uchylone zostaly postanowienia podjette na poprzednim sejmie ${ }^{94}$. Królewicze otrzymali prawo do rezydencji $\mathrm{i}$ do dochodów $\mathrm{w}$ jednej $\mathrm{z}$ dzierżaw $\mathrm{z}$ dóbr oprawnych po zmarkej w 1631 r. królowej Konstancji. Z kolei córce Zygmunta III - Annie Katarzynie wyznaczono na rezydencje starostwo brodnickie i golubskie, z których mogła korzystać aż do czasu swego zamążpójścia ${ }^{95}$. Królewna wydzierżawiła wspomniane starostwa na sześć lat Feliksowi Wiewierskiemu, który zobowiązal się zaplacić za pierwsze trzy lata kwotę 40 tys. guldenów ${ }^{96}$. $\mathrm{Z}$ pozostałych dóbr $\mathrm{z}$ oprawy po matce, które miały być rozdane szlachcie, przeznaczono dla jej dzieci pewne sumy (tak jednak, aby slusznq dzierżawcy

${ }^{89} \mathrm{VL}$, III, f. 495. Zwiększenie dochodów królewicza uzasadniano zasługami królewicza poniesionymi wobec Rzeczpospolitej w okresie dymitriady i wojny chocimskiej $1621 \mathrm{r}$. z Turcją.

${ }^{90}$ K. Chła powski, Starostowie w Malopolsce 1565-1668, [w:] Spoleczerístwo staropolskie. Studia $i$ szkice, t. IV, red. A. Izydorczyk, A. Wyczański, Warszawa 1986, s. 124, 131, 139-140, z odesłaniem MK 176, f. 34v-35. Starostwo hrubieszowskie w województwie ruskim należalo do tych, które przynosiły b. duży dochód, z kolei spośród starostw malopolskich do takich należało krzepickie, S. Ci a r a, Senatorowie $i$ dygnitarze..., s. 87, 96.

${ }^{91}$ K. Chłapowski, Starostowie..., s. 124 z odesłaniem MK 178, f. 51v-53.

${ }^{2}$ Acta sejmikowe województwa krakowskiego, t. II: 1621-1660, wyd. A. Przyboś, Wrocław-Kraków 1955, nr 25, s. 80: Mowa Stanislawa Lubomirskiego, wojewody ruskiego, na sejmiku przedsejmowym województwa krakowskiego w Proszowicach (31 sierpnia 1627 r.).

${ }^{93}$ VL, IIl, f. 709-710: Opatrzenie Nayiaśnieyszego Potomstwa naszego. W zamian za wyrażenie przez sejm zgody na opatrzenie królewskiego potomstwa, Zygmunt III zrezygnowal z dochodów menniczych. Zob. Kronika Pawla Piaseckiego..., s. 353.

${ }^{4}$ Postanowienie to odnosiło się do konstytucji $O$ wakancyach (VL, III, f. 668, pkt 6). Konstytucja z 1632 r. uchylała również konstytucję z roku 1609: Oprawa Krolowey IeyMci Konstancyi (VL, II, f. 1666, pkt 13), która postanawiała, iż żaden z potomków nie ma prawa ubiegać się o dobra oprawne po matce.

${ }^{95}$ PSB, I, red. W. Konopczyński, Kraków 1935, s. 134, s.v. Anna Katarzyna Konstancja (autor W. C z a pliński). Królewna czerpała dochody z tego starostwa do $1638 \mathrm{r}$., gdy osiąnęła wiek petnoletni. Zdaniem autorów Slownika Geograficznego Królestwa Polskiego, królewna trzymała starostwo tucholskie aż do 1642 r., czyli do chwili swego zamążpójścia za księcia neuburskiego Filipa Wilhelma - syna palatyna Renu, ibidem, t. 12, s. 590, s.v. Tuchola.

${ }^{96}$ Ks. P. Czaplewski, Senatorowie świeccy..., s. 86-87. 
mieli prowizya). Uchylono wówczas postanowienia konstytucji z 1609 r. zakazującej przekazywania dóbr oprawnych po królowej jej potomstwu ${ }^{97}$.

Królewna Anna Katarzyna otrzymała w 1632 r. 10 tys. zl. od ks. Stanisława Albrychta Radziwiłła - dzierżawcy starostwa tucholskiego. W latach następnych otrzymywała $\mathrm{z}$ tegoż starostwa po 15 tys. zł rocznie ${ }^{98}$. Po jej zamąż́ójściu (1642 r.), dochody te przejęła żona Władysława IV - Cecylia Renata. Królowa zażądała wówczas od S. A. Radziwiłła podwyższenia wypłat do 30 tys. zl rocznie. Chcąc utrzymać w posiadaniu starostwo tucholskie, kanclerz $\mathrm{z}$ trudem zaakceptowal podniesienie oplaty dzierżawnej do 27 tys. $\mathrm{zt}^{99}$. $\mathrm{Z}$ dochodów starostwa tucholskiego, po śmierci Cecylii Renaty, korzystała aż do $1667 \mathrm{r}$. druga żona Władysława IV - Ludwika Maria ${ }^{100}$.

Władysław IV, obejmując tron, zmuszony był rozdać trzymane przez siebie starostwa zasłużonym, co uczynił w 1633 r. Odmówiono wówczas jego prośbie, aby starostwo krzepickie jako uposażenie otrzymal Jan Kazimierz, zaś soleckie - Aleksander Karol ${ }^{101}$.

Król pamiętal jednak o uposażeniu swego mlodszego brata - Jana Kazimierza. W 1638 r. otrzymał on dochody ze starostwa sokalskiego, które pobierał do $1644 \mathrm{r}^{102} \mathrm{Na}$ sejmie $1641 \mathrm{r}$. uchwalono konstytucją ekspektatywę na dwa starostwa niegrodowe dla brata monarchy - jedno w Wielkim Księstwie Litewskim, drugie w Koronie ${ }^{103}$. W 1643 r. otrzymał on na Litwie starostwo puńskie ${ }^{104}$, następnie starostwo preńskie ${ }^{105}$. Starostwa będące w posiadaniu Jana Kazimierza zostały rozdane na sejmie 1645 r. decyzją króla i na prośbę królewicza, gdy ten postanowił wstąpić

${ }_{97}$ VL, II, f. 1666, zd. ostatnie, Oprawa Krolowej IeyMci Konstancyi. Zob. J. S e re dy ka, Rzeczpospolita w ostatnich latach panowania Zygmunta III (1529-1632). Zarys wewnetrznych dziejów politycznych, Studia i Monografie [Opole] 1978, nr 62, s. 202.

${ }_{98}$ Slownik Geograficzny Królestwa Polskiego, t. XII, s. 590; W. P a ł u ck i, Drogi i bezdroża..., s. $189, \mathrm{z}$ odesłaniem do A. S. R adziwiłł, Memoriale..., III, s. 95.

${ }^{99}$ Królowa miała otrzymywać 24 tys. zł i na podatek kawarciany 3 tys. zł, A. S. R a d zi wił 1 , Pamiętnik o dziejach $w$ Polsce, t. 2: 1637-1646, przekł. i oprac. A. Przyboś, R. Żelewski, Warszawa 1980, s. 310, 312, 312-313, 317.

${ }^{100}$ W 1660 r. królowa uzyskała zgodę na wydzierżawienie starostwa na okres trzech lat Erazmowi Janowskiemu i Zygmuntowi Kerszensteinowi; zob. ks. P. C z a ple w s ki, Senatorowie świeccy..., s. 206-207; S. Ci a ra, Senatorowie i dygnitarze..., s. 85. Po jej śmierci Tuchola bẹdzie oprawą królowej Eleonory - żony króla Michała Korybuta Wiśniowieckiego.

101 A. S. R a dziwiłł, Pamiętnik..., t. 1: 1632-1636, przekł. i oprac. A. Przyboś, R. Żelewski, Warszawa 1980, s. 293, 294; W. P a łu ck i, Drogi $i$ bezdroża..., s. 199, przyp. 301.

${ }^{102}$ K. Chła powski, Starostowie..., s. 145. Starostwo sokalskie należało do trzech starostw o najwyższej dochodowości w województwie bełskim, S. Ci a r a, Senatorowie i dygnitarze..., s. 94.

${ }^{103}$ VL, IV, f. 5 pkt 6: Prowizya krolewicza legomści Kazimierza.

104 A. S. R adziwił1, Pamiętnik..., t. 2: 1637-1646, s. 339, 335.

${ }_{105}$ Ibidem, s. 365. T. W a silew sk i, Ostatni Waza na polskim tronie, Katowice 1984, s. 36-37. 
do zakonu jezuitów ${ }^{106}$. Po odstąpieniu od zamiaru pozostania $w$ zakonie i powrocie do Rzeczypospolitej w grudniu 1646 r. rewindykuje należące doń wcześniej dobra: starostwo preńskie zwrócił mu Gotard W. Butler, ponadto uzyskał administrację nad ekonomią kobryńską ${ }^{107}$. Trudniej było Janowi Kazimierzowi przywrócić władanie nad starostwem sokalskim. Starostwo to trzymał Zygmunt Denhof - zięć kanclerza koronnego Jerzego Ossolińskiego, który nie chcial z niego ustąpić ${ }^{108}$. Między stronami doszlo jednak do ugody, w wyniku której brat króla, tytułem rekompensaty za utracone starostwo, otrzymywal od Denhofa rocznie 16 tys. $\mathrm{z}^{109}$. Sejm $1647 \mathrm{r}$. wyrazil, aczkolwiek bardzo niechętnie, zgodę na zatrzymanie przez Jana Kazimierza odebranych królewszczyzn ${ }^{110}$. Królewicz odzyskał wówczas również inne posiadane wcześniej dobra. Będąc monarchą, pobieral dochody $w$ latach $1650-1656$ ze starostwa drohobyckiego $^{111}$.

Po śmierci podskarbiego wielkiego koronnego Jana M. Daniłowicza król nadal swej żonie - królowej Ludwice Marii, starostwo dolinskie $(1650$ r.), gdyż dobra wchodzące w skład jej oprawy zostały wcześniej rozdane i nie otrzymywała $\mathrm{z}$ nich należnych dochodów ${ }^{112}$.

Jan Sobieski, wstępując na tron, posiadał inną niż Zygmunt III pozycję majątkową ${ }^{113}$. Przed objęciem tronu trzymał on starostwa jaworowskie ${ }^{114}$,

106 Slownik geograficzny Królestwa Polskiego, t. 9, s. 34, s.v. Preny; A. S. R a d zi iwiłł, Pamiętnik..., t. 2, s. 367, 414; T. W a silew sk i, Ostatni Waza..., s. 46-47. Mimo głosów, aby zatrzymać starostwa przez okres dwóch lat, dopóki nie zakończy się dla królewicza okres nowicjatu, starostwa zostały rozdane.

107 Ekonomia kobryńska była wcześniej w oprawie jego matki królowej Konstancji.

${ }_{108}$ A. S. R adziwił1, Pamietnik..., t. 3: 1647-1656, s. 12.

${ }^{109} \mathrm{Z}$. Denhol zachował dla siebie od 3 tys. do 4 tys. zł $z$ dochodów ze wspomnianego starostwa; ibidem, s. 52; Z. Wó j ci k, Jan Kazimierz Waza, Wrocław-Warszawa-Kraków 1997, s. 39.

${ }^{110}$ T. Wasilewski, Ostatni Waza..., s. 53.

${ }^{111}$ K. Chłapowski, Starostowie w Malopolsce 1565-1668, [w:] Spoleczeństwo staropolskie, t. IV red. A. Wyczański, Warszawa 1986, s. 138, z odesłaniem: Jakuba Michalowskiego [...] Ksiega pamiętnicza..., wyd. C. K. Tow. Nauk. Krakowskie, wstęp A. Z. Helcel, s. 817.

${ }^{112} \mathrm{Na}$ starostwo dolinskie sila sobie ostrzyli żeby, ale sie tym wszytkim oszukanie stalo, bo sie Królowej w prowizyej wyżej pomienionej dostalo; S. Oświęci m, Diariusz 1643-1651, wyd. W. Czermak, Kraków 1907, s. 212, 222. Zob. K. Chłapowski, Starostowie..., s. 138, z odesłaniem MK 191, f. 350v-352, Jakuba Michalowskiego [...] Ksiega pamiętnicza..., s. 811.

113 Zwróciła na to uwage A. Filipczak-Kocur, wskazując na fakt, iż Michał Korybut Wiśniowiecki posiadał również dobra rodowe; t e jże, Skarbowość Rzeczypospolitej..., s. 42. Podobnie pozycja Augusta II Sasa, jak i jego syna - Augusta III, była korzystniejsza, gdyż mogli oni dysponować zasobami materialnymi Saksonii.

${ }^{114}$ Starostwo jaworowskie przejął, po ojcu Jakubie Sobieskim, zob. Z. W ó jcik, Jan Sobieski..., s. 45, z odesłaniem MK 190, f. 328r-330v.; K. Chłapowski, Starostowie..., s. 140, $z$ odesłaniem MK 189 , f. $85-85 \mathrm{v}$. 
Tadeusz Szulc

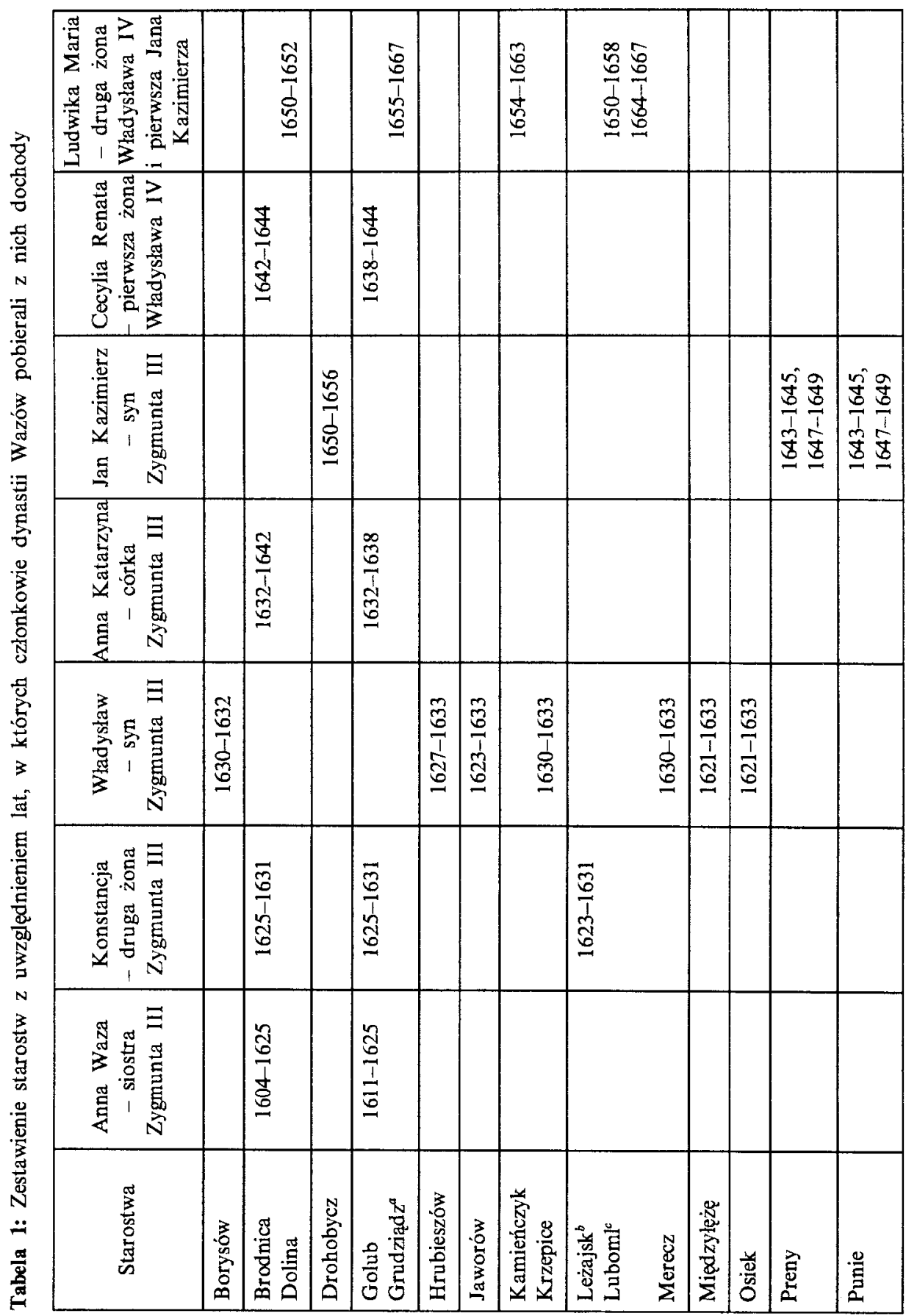




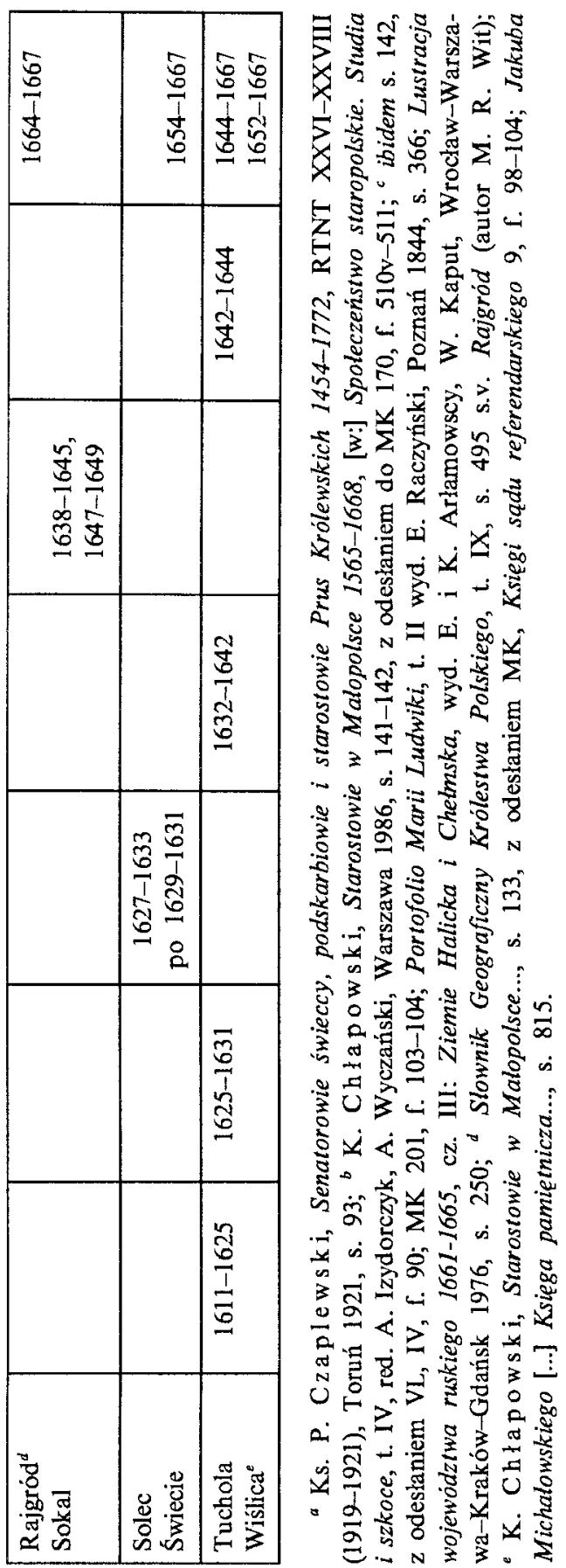


stryjskie $^{115}$, kałuskie ${ }^{116}$ i gniewskie ${ }^{117}$. Tytułu starosty tucholskiego używał Sobieski w 1672 r. $^{118} \mathrm{~W} 1673 \mathrm{r}$. kasztelan poznański Jan Opaliński otrzymał konsens na cesję starostwa międzyłęskiego i osieckiego na rzecz Jana Sobieskiego i Marii Kazimiery ${ }^{119}$. W tymże roku król stał się posiadaczem starostwa osieckiego ${ }^{120}$.

Obejmują tron, Sobieski winien był zrzec się trzymanych dotychczas starostw. Aby nie pozbawiać Jana III jako monarchy dochodów z trzymanych przezeń starostw, uczyniono dlań w 1676 r. wyjątek: konstytucją Starostwa dożywociu naszemu podlegle sejm zezwolił królowi i jego matzonce królowej Marii Kazimierze trzymać w dożywociu starostwa, które posiadali wcześniej ${ }^{121}$. Zastrzeżono, iż administracja starostwa winna być sprawowana przez szlachtę osiadłą; podlegały one wszystkim ciężarom - tak jak inne dobra ziemskie. Po śmierci monarchy starostwa te miały być wynagrodzeniem dia osób zasłużonych.

W 1668 r. Jan Sobieski podjął starania o wykupienie starostwa puckiego z rąk Gdańska ${ }^{122}$, które po dhugotrwałych targach zostały w 1678 r. uwieńczone sukcesem króla ${ }^{123}$. Od 1687 r. w ręku Jana III znalazło się starostwo kozienickie ${ }^{124}$.

${ }^{115}$ Pisma do wieku i spraw Jana Sobieskiego, zebr. i wyd. F. Kluczycki, t. I, cz. II, Kraków 1881, s. 983, nr 365; O. F. de B attaglia, Jan Sobieski król Polski, Warszawa 1983, s. 29. Jan Sobieski uzyskał w posiadanie starostwo stryjskie w 1660 r., S. Ci a r a, Senatorowie $i$ dygnitarze..., s. 65, z odesłaniem do: Maria Kazimiera d'Arquien de la Grange, Listy do Jana Sobieskiego, oprac. L. Kukulski, Warszawa 1966, s. 109 - komentarz wydawcy.

${ }^{116}$ Uzyskał je w w 1667 r.; K. Chłapow ski, Starostowie..., s. 140; S. Ciara, Senatorowie $i$ dygnitarze..., s. 68 .

117 W 1665 r. Jan Sobieski wystarał się o przywilej z ,okienkiem" na to starostwo, a otrzymał je po 1667 r., w 1668 r. uzyskał ius communicativum dla swej żony Marysienki, zob. I. S t rzele ck a, Gniew, Wrocław-Warszawa-Kraków-Gdańsk-Lódź 1982, s. 26; S. C i a r a, Senatorowie $i$ dygnitarze..., s. 86 - w województwie pomorskim Gniew zaliczano do starostw przynoszących duze dochody. W 1673 r. starostwo to nadano Janowi Sobieskiemu na 4 pokolenia $z$ wdzięczności za przyslugi, jakie poniósl okolo ojczyzny; Slownik Geograficzny Królestwa Polskiego, t. II, s. 626, s.v. Gniew (autor Kś. Fankidejski).

${ }^{118}$ S. Ci a r a, Senatorowie $i$ dygnitarze..., s. 85. Starostą tucholskim pozostawał w zasadzie Jan Andrzej Morsztyn, loc. cit.

119 Ibidem, s. 86. Międzyłęskie starostwo król trzymal aż do śmierci, Maria Kazimiera będzie w posiadaniu starostwa do $1699 \mathrm{r}$.

${ }^{120}$ Ks. P. Czaplewski, Senatorowie świeccy..., s. 152.

121 VL, V, f. 356, pkt 28.

${ }^{122} \mathrm{~W} 1655$ r. starostwo było w ręku Teresy Zawadzkiej - wdowy po staroście Janie Zawadzkim, która miała ius communicativum. W $1656 \mathrm{r}$. Jan Kazimierz przekazał starostwo wraz z dochodami Gdańskowi w zamian za obowiązek obrony starostwa. Dochody ze starostwa nie wystarczały na pokrycie tych kosztów, miało ono pozostawać pod zarządem Gdańszczan do czasu uzyskania pełnego zwrotu poniesionych przez nich wydatków; E. Cieślak, Przetargi..., s. 142, z odesłaniem do: WAPG, 300, 27/86, f. 40.

${ }^{123}$ E. Cieślak, Przetargi..., s. 150-154; zob. Ks. P. Czaplewski, Senatorowie świeccy..., s. 164. Król musiał wczesniej zaspokoić pretensje spadkobiercy starościny T. Zawadzkiej. Sobiescy trzymali to starostwo do stycznia 1717 r., wówczas nowy starosta Jan Jerzy Przebendowski wypłacił Jakubowi i Konstantemu Sobieskim sumę zastawną 120 tys. guldenów ciążącą na Pucku.

124 R. R y barsk i, Skarb $i$ pieniqudz..., s. 481. Zob., przyp. 52 naszego artykułu. 


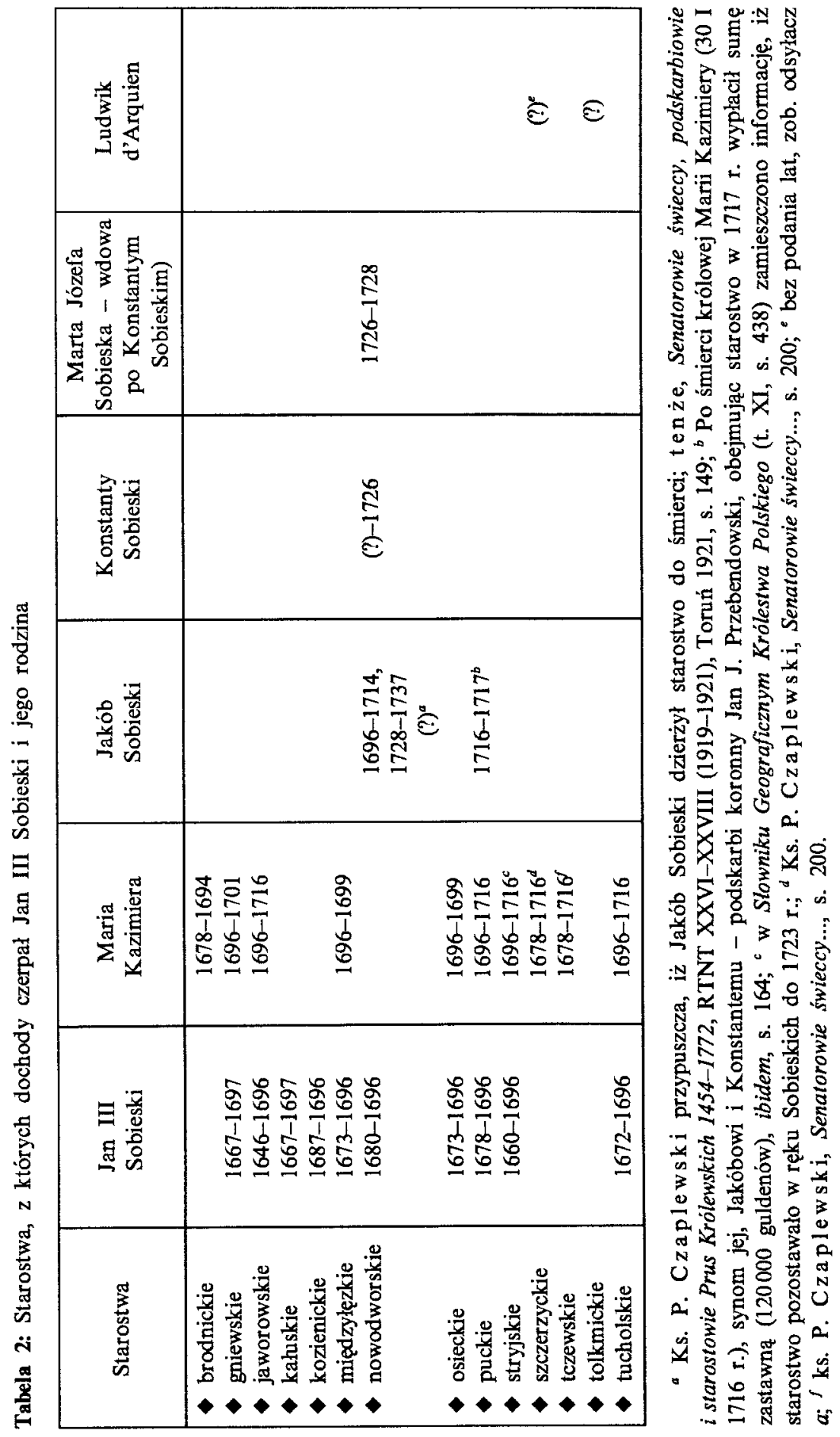


Na dworze Jana III Sobieskiego przebywali długo bliscy krewni królowej Marysieńki ${ }^{125}$. Królowa - jak pisze Z. Wójcik - bardzo troszczyła się o nich. Brat królowej Ludwik d’Arquien, hrabia Maligny został obdarowany starostwami: tolkmickim i szczerzyckim ${ }^{126}$.

Również Stanislaw August Poniatowski nadawał starostwa swoim braciom. Brat Stanisława Augusta - Andrzej Poniatowski otrzymal po nim, przynoszące duże dochody, starostwo przemyskie ${ }^{127}$. Z chwilą, gdy odstąpił je K. Branickiemu, uzyskał $w$ zamian od brata pensję 5 tys. dukatów rocznie ${ }^{128}$. Dzięki bratu i M. Czartoryskiemu otrzymal w $1768 \mathrm{r}$. na Litwie starostwa preneńskie i upickie, zaś w $1771 \mathrm{r}$. dla żony - starostwo wielońskie ${ }^{129}$. Po śmierci męża, księżna wdowa scedowała starostwo na rzecz syna - ks. Józefa Antoniego, co zatwierdził sejm 1773-1775 r. osobną konstytucją. Ze starostwa tytulem kwarty wplywała do skarbu opłata w wysokości 18628 złp. 8 gr $^{130}$, co dowodzi, iż dochody z niego czerpane byly duże. W 1775 r. król Stanisław August dokonal na rzecz jego i jego potomków cesji starostwa chmielnickiego ${ }^{131}$, z którego Ossolińscy jako dożywotni posiadacze uzyskiwali kilkaset tysięcy zlp. ${ }^{132}$. Następnie uzyskał on starostwa: żyzmorskie i uszpolskie. W $1792 \mathrm{r}$. król Stanisław August Poniatowski ofiarował mu intratę 100 tys. złp. rocznie ${ }^{133}$.

Kazimierz Poniatowski - brat króla, uzyskał nadanie 24 XII 1764 r. starostwa spiskiego ${ }^{134}$, zastawionego Królestwu Polskiemu w 1412 r. przez

${ }^{125}$ M. Ko mas z y ń ski, Maria Kazimiera D'Arquien Sobieska królowa Polski 1641-1716, Kraków 1983, s. 101-102.

${ }^{126}$ Z. Wójcik, Jan Sobieski..., s. 407, bez odesłania do źródeł.

${ }^{127}$ Starostwo przemyskie, obok stryjskiego, należało do najbogatszych w województwie ruskim, T. Zi e li ńs k a, Magnateria polska epoki saskiej. Funkcje urzędów i królewszczyzn w procesie przeobrażeń warstwy spolecznej, Wrocłąw-Warszawa-Kraków-Gdańsk 1977, s. 158. Stanisław August uzyskał to starostwo w $1752 \mathrm{r}$. od rodziców. Tytułem kwarty ze starostwa wpłacano do skarbu 17656 złp., ibidem, s. 159, z odesłaniem do: Sig. 27, 240.

128 PSB, t. XXVIl/3, red. E. Rostworowski, Wrocław-Warszawa-Kraków-Gdańsk-Lódź 1983, s. 415, s.v. Poniatowski Andrzej h. Ciolek (autor E. R o stworow ski). Autor biogramu wskazuje, iż informacja o pensji pochodzi $z$ wątpliwej relacji S. Lubomirskiego.

${ }^{129}$ Ibidem, s. 418; zob. Slownik Geograficzny Królestwa Polskiego, t. XIII, s. 360, s.v. Wielona (autor J. Krz.).

130 Slownik Geograficzny Królestwa Polskiego, t. XIII, s. 360.

131 Ibidem, t. I, s. 589, s.v. Chmielnik (autor Dr. Maryański); Inwentarz Archiwum księcia Józefa Poniatowskiego i Marii Teresy Tyszkiewiczowej, oprac. M. Józefowiczówna, Warszawa 1987 , s. 41.

${ }^{132}$ S. A s k e n a z y, Ksiqże Józef Poniatowski, Warszawa 1974, s. 52; J. S k o w r on e k, Ksiqże Józef Poniatowski, Wrocław-Warszawa-Kraków-Gdańsk-Lódź 1984, s. 13.

${ }^{133}$ S. A sken azy, Książe Józef Poniatowski, s. 71; autor wskazuje zarazem, iż wpomniane nadanie, wskutek kasaty uchwał sejmowych przez targowiczan, nie dostało się w ręce księcia. Targowica objęła sekwestrem dochody ze starostw: wielońskiego i żyzmorskiego; ibidem, s. $87-88$.

134 Wszyscy tedy zyskali, tak magnaci, jako i mniejszego wzgledu obywatele w sejmie elekcyjnym koronnym $1764 i$ w sejmie $1766 r$. to wszystko, czego ich interesa wymagaly [...] Osobliwie Karolowi <Brühlowi > odebrano jedno starostwo spiskie i to po koronacyi dal król bratu 
Zygmunta Luksemburczyka. Nadanie uzasadniano kosztami ponoszonymi przez królewskiego brata na utrzymanie regimentu gwardii koronnej. Starostwo spiskie należało do jednego $\mathrm{z}$ najbogatszych starostw w Rzeczpospolitej, przynosząc rocznie ok. 16-18 tys. czerwonych złotych dochodu, co stanowiło równowartość 232 tys. złp. ${ }^{135}$ Brat króla trzymal również starostwa stryjskie i sokalskie ${ }^{136}$. Sejm $1774 \mathrm{r}$. przyznał temuż dziedziczne starostwo i wójtostwo szadowskie w powiecie upickim. Były one rekompensatą za utratę w wyniku I rozbioru starostwa spiskiego oraz wynagrodzeniem za poniesione koszty utrzymania regimentu gwardii konnej w czasie konfederacji barskiej ${ }^{137}$. W 1779 r. dochody ze starostwa przelał na żonę i syna Stanisława ${ }^{138}$. Sejm czteroletni potwierdzil dziedziczny charakter nadania starostwa szadowskiego, uwalniając posiadaczy w kwietniu $1790 \mathrm{r}$. od nałożonego na dobra królewskie 30-procentowego podatku od dochodu ${ }^{139}$.

Stanisław - syn Kazimierza Poniatowskiego, cieszył się dużą protekcją króla, który dążyl do stworzenia [bratankowi - T. S.] silnej pozycji materialnej $i$ osobistej $j^{140}$. W 1777 r. król scedował na niego dwa bogate starostwa: kaniowskie $\mathrm{i}$ bohusławskie ${ }^{141}$, które nadano królowi $i$ jego sukcesorom dziedzicznym prawem na sejmie $1775 \mathrm{r}^{142}$ Dożywotnim posesorem starostwa kaniowskiego byl kasztelan lwowski Jan Potocki, zaś bohusławskiego - Franciszek Rzewuski. W posiadanie starostwa kaniowskiego ks. Stanisław wszedł zapewne w połowie lat osiemdziesiątych, wykupując je od Potockiego ${ }^{143}$. Kiedy i jak przejąl starostwo bohusławskie nie wiadomo. Wcześniej, za zgodą króla, od siostry króla Izabeli Branickiej otrzymal cesje starostwa bielskiego, na którym zachowała ona potwierdzone przez sejm $1773 / 75$ dożywocie ${ }^{14}$. Nadano mu również starostwo bobrujskie ${ }^{145}$. W 1780 r. Kacper Rogaliński - dotychczasowy

swemu, ksieciu Kazimierzowi..., [w:] Pamiętniki z osiemnastego wieku, t. IX: Pamiętnik do historyi polskiej $i$ ostatnich lat panowania Augusta III i pierwszych Stanislawa Poniatowskiego, wyd. A. Moszyński, Poznań 1867, s. 65; PSB, XXVII/3, s. 447, s.v. Poniatowski Kazimierz h. Ciolek (autor Z. Zielińska).

${ }^{135}$ K. Zienk owska, Stanislaw August Poniatowski, s. 146.

136 Ze starostwa sokalskiego kwarta wynosiła 20683 złp., T. Zieli ń sk a, Magnateria..., s. 158.

${ }^{137}$ PSB, t. XXVII/3, s. 449. Utracił wówczas starostwo stryjskie. Dochody, które otrzymywał dotychczas z tych starostw, zastąpił cesarz Józef II w $1774 \mathrm{r}$. dożywotnią pensją w wysokości 6 tys. dukatów; ibidem, s. 450.

${ }_{138}$ PSB, XXVII/3, s. 450, s.v. Poniatowski Kazimierz h. Ciolek.

139 Loc. cit.

140 PSB, XXVII, s. 482, s.v. Poniatowski Stanislaw h. Ciolek (autor J. M i ch a lsk i).

${ }^{41}$ Starostwa te należały do królewszczyzn w województwie ruskim, z których płacono do skarbu najwyższą kwartę; z bochusławskiego wynosiła ona 33895 złp., zaś z kaniowskiego 22299 złp., T. Zi eli ńs k a, Magnateria..., s. 128, 202.

${ }^{142}$ VL VIII, f. 209-210: Wdzięczność Nayiaśnieyszemu Królowi. Miała to być rekompensata za przekazanie na rzecz sejmu prawa rozdawnictwa starostw po śmierci Stanisława Augusta.

${ }_{143}$ Slownik Geograficzny Królestwa Polskiego, t. III, s. 811, s.v. Kaniów (autor Ed. Rulikowski).

14 PSB, XXVII, s. 482.

145 Loc. cit. 
dzierżawca wieczysty starostwa korsuńskiego, odstąpił swe prawa doń bratankowi królewskiemu ${ }^{146}$. W 1782 r. Stanisław Poniatowski nabył starostwo winnickie ${ }^{147}$, z którego w 1789 r. uzyskał 81881 złp. dochodu ${ }^{148}$.

Tabela 3: Starostwa, z których dochody czerpali bracia i bratankowie króla Stanisława Augusta Poniatowskiego

\begin{tabular}{|c|c|c|c|c|}
\hline Starostwa & $\begin{array}{l}\text { Ks. Andrzej } \\
\text { Poniatowski } \\
\text { - brat króla }\end{array}$ & \begin{tabular}{|} 
Ks. Józef Antoni, \\
Poniatowski \\
- bratanek
\end{tabular} & $\begin{array}{l}\text { Ks. Kazimierz } \\
\text { Poniatowski } \\
\text { - brat króla }\end{array}$ & $\begin{array}{l}\text { Ks. Stanisław } \\
\text { Poniatowski } \\
\text { - bratanek }\end{array}$ \\
\hline $\begin{array}{l}\text { bielskie } \\
\text { bobrujskie } \\
\text { bohusławskie } \\
\text { chmielnickie } \\
\text { korsuńskie } \\
\text { kamienieckie } \\
\text { kaniowskie } \\
\text { preneńskie } \\
\text { przemyskie } \\
\text { sokalskie } \\
\text { spiskie } \\
\text { stryjskie } \\
\text { szadowskie } \\
\text { upickie } \\
\text { uszpolskie } \\
\text { wielonskie } \\
\text { winnickie } \\
\text { żyżmorskie }\end{array}$ & $\begin{array}{c}1768-1773 \\
1764 \\
\\
1768-1773 \\
1771-1773\end{array}$ & $\begin{array}{c}1779-1793 \\
\\
\\
1773-1798 \\
1773-1793, \\
1797 \\
1773-1793 \\
1797-1801\end{array}$ & $\begin{array}{l}1750-1770 \\
1764-1773 \\
1756-1773 \\
1774-1779\end{array}$ & $\begin{array}{l}\text { bez wskazania lat } \\
\text { j.w. } \\
1777-1798 \\
\\
1780-1793 \\
1785-1797 \\
1777-1793 \\
\\
1779-1798 \\
\\
1782-1797\end{array}$ \\
\hline
\end{tabular}

Starostwa uzyskiwane przez członków rodziny królewskiej należały do najbardziej dochodowych królewszczyzn w Rzeczypospolitej..

4.2.2. Nominacyjne uprawnienia monarchy obejmowały, poza urzędami świeckimi również godności duchowne, między innymi arcybiskupstwa, biskupstwa i opactwa ${ }^{149}$.

Nadania godności kościelnych na rzecz członków rodziny królewskiej miały miejsce już za panowania Piastów i Jagiellonów. Ograniczmy się do podania dwóch przykładów. Jadwiga - dziesiąte dziecko ks. Henryka II

\footnotetext{
${ }^{146}$ Slownik Geograficzny Królestwa Polskiego, t. V, s. 44, s.v. Korsuń (autor E. Rulikowski). Starostwo przynosilo dochodu $129150 \mathrm{zl} 12 \mathrm{gr}$.

${ }^{147}$ R. Kaleta, Odrodny kuzyn księcia Józefa (Uwagi w zwiqzzu z ksiqżka M. Brandysa „Niezlomny ksiaże Poniatowski”), Przegl. Hum. 1961, R. V, nr 4 (25), s. 103.

${ }^{148}$ Slownik Geograficzny Królestwa Polskiego, t. XIII, s. 556, 557, s.v. Winnica (autor Dr. Maryański).

149 J. Matuszewski, Sprzedawalność urzędów w Polsce, CPH 1964, t. XVI, z. 2, s. $109-110$.
} 
Pobożnego, została opatka klasztoru klarysek we Wrocławiu ${ }^{150}$. Fryderyk Jagiellończyk - szósty syn króla Kazimierza, został przeznaczony do stanu duchownego, a celem tego kroku było utrwalenie wpływów monarchy i dynastii w Kościele w Polsce ${ }^{151}$. Przy zachowaniu pozorów elekcji wola monarchy decydowała o obsadzie urzędów biskupich i arcybiskupich ${ }^{152}$. Nadanie godności biskupiej królewiczowi było formą zabezpieczenia materialnego; otrzymywał on $\mathrm{z}$ reguły diecezje przynoszące duże dochody i związane $\mathrm{z}$ nimi wysokie miejsce $w$ senacie ${ }^{153}$. Urzędy biskupie $w$ Rzeczypospolitej, $z$ uwagi na dochodowość i rolę, jaką odgrywały w życiu publicznym ${ }^{154}$, były atrakcyjnymi stanowiskami, o które zabiegano.

Starania o to, aby Andrzej Batory - bratanek króla Stefana, uzyskal biskupstwo warmińskie, podjęte zostały w $1581 \mathrm{r} .{ }^{155}$ Wówczas, dzięki poparciu monarchy otrzymał on kanonię warmińską. W $1583 \mathrm{r}$. nadane mu zostało probostwo w Miechowie ${ }^{156}$. Na wniosek króla Stefana Batorego, mimo sprzeciwów kapituły, papież mianował Andrzeja Batorego w 1584 r. kardynałem ${ }^{157}$ i koadiutorem diecezji warmińskiej ${ }^{158}$. Biskupstwo warmińskie uzyskał on, już po śmierci króla, w 1589 r. ${ }^{159}$ Pod względem uposażenia biskup warmiński zajmował wysoką, siódmą lokatę (na trzynaście) w Rzeczpospolitej ${ }^{160}$.

150 Piastowie. Leksykon biograficzny, red. S. Szczur, K. Ożóg, Kraków 1999, s. 420, s.v. Jadwiga (autor T. Jurek).

151 Został biskupem krakowskim i arcybiskupem gnieznieńskim, zob. PSB, VII, red. K. Lepszy, Kraków 1948-1958, s. 167, s.v. Fryderyk Jagiellończyk (autor ks. H. R y b u s).

152 Historia państwa i prawa polskiego, t. II: od polowy XV wieku do r. 1795, red. J. Bardach, Warszawa 1966 , s. $80-81$; Z. R y m a s zew s k i, $O$ stosunkach między państwem a kościolem w Polsce $w$ świetle akt kapitulnych i konsystorskich z lat 1403-1533, Acta Univ. Lodz. 1993, Folia Iuridica 56, s. 66.

${ }^{153}$ J. D zi ̨̨̨ i el e wski, Biskupi rzymskokatoliccy końca XVI-pierwszej polowy XVII w. $i$ ich udzial w ksztaltowaniu stosunków wyznaniowych $w$ Rzeczypospolitej, [w:] Między monarchiq a demokracja. Studia $z$ dziejów Polski XV-XVIII wieku, red. A. Sucheni-Grabowska, M. Żaryn, Warszawa 1994, s. 199.

${ }^{154}$ Nieprawy syn Zygmunta I - Jan zostal mianowany przez papieża Leona X biskupem wileńskim $\mathrm{z}$ prawem zachowania dochodów $\mathrm{z}$ kanonii płockiej; objął rządy nie przyjmując święceń. Realizował na życzenie ojca politykę mającą na celu wzmocnienie stanowiska dynastii na Litwie $\mathrm{i} w$ Polsce, PSB, X, s. 440, s.v. Jan $z$ Ksiqżqt Litewskich (autor A. $S$ wi i ża ws ki).

155 Owczesny biskup warmiński - Marcin Kromer, liczyl lat 69.

${ }^{156}$ Encyklopedyja Powszechna [Orgelbranda], t. I, Warszawa 1860, s. 1015, s.v. Batory Jędrzej (autor K. Wł. Wójcicki); T. Oracki, Slownik biograficzny Warmii, Prus Ksiażęcych i ziemi malborskiej od polowy XV do końca XVIII wieku, Olsztyn 1984, s. 12, s.v. Batory Andrzej.

157 W. Konopczyński, Dzieje Polski nowożytnej, t. 1, Warszawa 1989, s. 168. Zob. też uwage J. Dzį̨gielewski, Biskupi..., s. 194 i 199.

${ }^{158}$ Stanowisko koadiutora biskupiego miało zapewnić ciągłość rządów po obecnie pelniącym urząd biskupie; gdy ten zmarł, koadiutor obejmowal po nim stanowisko; A. S z o r c, Dominium warmińskie 1243-1772. Przywilej i prawo chelmińskie na tle ustroju Warmii, Olsztyn 1990, s. 146.

${ }_{159}$ PSB, I, s. 352, s.v. Batory Andrzej (autor T. G 1 e m m a).

${ }^{160}$ Ks. B. K u m o r, Historia Kościola, cz. 5: Czasy nowożytne. Rozlam w chrześcijaństwie zachodnim, Lublin 1984, s. 114. 
Tabela 4

\begin{tabular}{|c|c|c|c|c|c|}
\hline \multicolumn{1}{c|}{} & $\begin{array}{c}\text { Kanonik } \\
\text { warmiński }\end{array}$ & $\begin{array}{c}\text { Probostwo } \\
\text { w Miechowie }\end{array}$ & Kardynał & $\begin{array}{c}\text { Koadiutor } \\
\text { diecezji } \\
\text { warmińskiej }\end{array}$ & $\begin{array}{c}\text { Biskupstwo } \\
\text { warmińskie }\end{array}$ \\
\hline $\begin{array}{c}\text { Andrzej Batory } \\
\text { (ur. 1563 r.) }\end{array}$ & $1581-1599$ & 1583 & $1584-1599$ & $1584-1589$ & $1589-1599$ \\
\hline
\end{tabular}

- Jan Albert - trzeci syn Zygmunta III Wazy, zostal mianowany biskupem warmińskim, gdy osiągnął lat dziewięć $(1621 \mathrm{r} \text {. })^{161}$. Nominacja spotkała się na sejmiku proszowskim w grudniu $1622 \mathrm{r}$. ze sprzeciwem posłów krakowskich ${ }^{162}$, zaś na sejmach 1623, 1624, 1625 i 1626 r. wywolała ostrą dyskusję ${ }^{163}$. Posłowie na sejmie 1623 r. argumentowali, że jeżeli monarcha chce zaopatrzyć potomstwo to powinien w tej sprawie zwrócić się do Rzeczypospolitej a nie lamać prawo ${ }^{164}$. Posłowie sprzeciwiali się oddaniu bogatego biskupstwa w ręce członka rodziny królewskiej. $Z$ kolei na następnym sejmie monarcha sprzeciwiał się porównywaniu królewicza $z$ cudzoziemcem Andrzejem Batorym, argumentując, iż Jan Albert wywodzi się od Jagiellonów, urodził się jako polski szlachcic, a zatem przyshugiwały mu wszelkie wynikające $\mathrm{z}$ tego prawa ${ }^{165}$. Na sejmie $1626 \mathrm{r}$. król odmówił złożenia przyrzeczenia, iż w przyszłości nie bẹdzie nadawał podobnych godności potomkom ${ }^{166}$. Dopiero w $1631 \mathrm{r}$. sejm wyraził zgodę na doraźne złamanie prawa $w$ postaci nadania biskupstwa królewiczowi ${ }^{167}$.

161 PSB, X/3, red. K. Lepszy, Wrocław-Warszawa-Kraków 1962-1964, s. 422, s.v. Jan Albert (autor T. Nowak). Kapituła warmińska mająca prawo do swobodnego wyboru biskupa spośród czterech kandydatów wysuniẹtych przez króla, będących kanonikami, była przeciwna decyzji Zygmunta III. Król wskazał wówczas tylko jedną kandydaturę - swego syna, stąd wybór był formalnością, J. Pietrzak, W przygaszonym blasku wiktorii chocimskiej. Sejm w 1623 r., Acta Univ. Wratisl. 1987, No 890, Historia LVII, s. 76, przyp. 36.

${ }_{162}$ Akta sejmikowe województwa krakowskiego, t. II, s. 9-16: Instrukcja z sejmiku proszowickiego 13 XII 1622 roku.

163 J. B a r tos zewicz, Królewicze biskupi. Żywoty czterech kaplanów, Warszawa 1851, s. 152 i n.; W. Czaplińsk i, Wiek siedemnasty w Polsce. Próba charakterystyki, [w:] O Polsce siedemnastowiecznej. Problemy $i$ sprawy, Warszawa 1966, s. 45, z odesłaniem reces sejmu z 1623 r., Rkps WAP Gdańsk 300/29/102, k. 151; J. P i t r zak, $W$ przygaszanym blasku..., s. 77-78; J. Do r o bis z, Sejm nadzwyczajny z 1624 roku, Opole 1994, s. 71-72; J. K w a k, Sejm warszawski..., s. 23, 44, 92-93; A. F i li pczak-K ocu r, Sejm nadzwyczajny z roku 1629, Warszawa-Wroclaw 1979 , s. 48.

164 J. Pi etrzak, $W$ przygaszanym blasku..., s. 79.

165 J. Doro bis z, Sejm nadzwyczajny z I624 roku, Opole 1994, s. 71, z odesłaniem: bk, 201, k. 224; DZAM, Rep. 6, No 36, fasz. 1, k. 5 .

166 J. Kwak, Sejm warszawski..., s. 95.

${ }^{167}$ VL, III, f. 668, Warmia; J. S e r e d y k a, Rzeczpospolita w ostatnich latach panowania Zygmunta III (1629-1632). Zarys wewnetrznych dziejow politycznych, Studia i Monografie [Opole] 1978 , No 62 , s. $119-120$. 
Król, na krótko przed śmiercią, przeforsował mianowanie Jana Alberta na biskupstwo krakowskie ${ }^{168}$, na co ostatecznie zezwolił sejm koronacyjny w 1633 r. ${ }^{169}$ Biskupstwo krakowskie pod względem wysokości dochodów znajdowało się na drugim miejscu w Rzeczpospolitej, po arcybiskupstwie gnieźnieńskim ${ }^{170}$.

Tabela 5

\begin{tabular}{|c|c|c|c|}
\cline { 2 - 4 } \multicolumn{1}{c|}{} & Biskupstwo warmińskie & Biskupstwo krakowskie & Kardynał \\
\hline $\begin{array}{c}\text { Jan Albert Waza } \\
\text { (ur. } 1612 \text { r.) }\end{array}$ & $1621-1632$ & $1632-1634$ & $1633-1634$ \\
\hline
\end{tabular}

Karol Ferdynand Waza - kolejny syn Zygmunta III, w wieku lat siedmiu, dzięki wstawiennictwu matki królowej Konstancji zostal koadiutorem biskupstwa wrocławskiego (1620 r.), mając lat dwanaście, został wybrany biskupem wrocławskim $(1625 \mathrm{r} .)^{171}$. Ze względu na zniszczenia wojenne biskupstwa, na sejmie 1632 r. podjęto sprawę wyznaczenia zaopatrzenia dla Karola Ferdynanda ${ }^{172}$. Król Władysław IV - jego starszy brat, nadał mu w 1633 r. na okres czterech lat prawo rezydencji w przynoszącym duże dochody opactwie czerwińskim ${ }^{173}$. Królewicz trzymał wspomniane opactwo aż do 1641 r. ${ }^{174}$ Analogiczne prawo w formie ekspektatywy, na okres sześciu lat, uzyskał on w $1635 \mathrm{r}$. na opactwie tynieckim, gdy tylko będzie wakans ${ }^{175}$.

${ }^{168}$ Andrzej Lipski - biskup krakowski, zmarł w 1631 r.

169 VL, III, f. 791-792, pkt 19: Konsens na Biskupstwo Krakowskie. W konstytucji postanowiono, iż królewicz winien zostać $w$ ciągu trzech lat, za zezwoleniem papieża, prezbitrem. Miał korzystać z takich samych uprawnień jak jego poprzednicy - biskupi. We wszystkich sprawach sądowych podlegał prawu ziemskiemu, wszystkim ciężarom i obowiązkom wzgleddem państwa. Nie przysługiwało mu uprawnienie do nominandi, inaugurandi, coronandi Regis. Jako kardynał nie może korzystać z uprawnień należnych prymasowi. Gdyby uzyskał stanowisko poza królestwem polskim, winien złożyć godność biskupią. Zob. też PSB, X/3, s. 422.

${ }_{170}$ Ks. B. Ku mor, Historia Kościola, cz. 5, s. 114.

${ }_{171}$ PSB, t. XII/1, red. E. Rostworowski, Wrocław-Warszawa-Kraków 1966, s. 85, s.v. Karol Ferdynand Waza (autor W. Cza pli ńsk i). Obaj wymienieni synowie Zygmunta III, powołani na stanowiska biskupie, do końca życia nie przyjęli święceń kapłańskich, J. Seredyka, Rzeczpospolita..., s. 201.

17 A. S. R a dziwiłł, Pamiętnik..., t. 1, s. 177.

173 VL, III, f. 792, pkt 20: Konsens na Opactwo Czerwinskie.

174 Slownik Geograficzny Królestwa Polskiego, t. I, s. 838, s.v. Czerwińsk (autor Br. Cblebowski). $\mathrm{Na}$ sejmie 1639 r. posłowie domagali się stanowczo odebrania opactwa królewiczowi, któremu skończył się okres rezydencji. Po długich sporach na wniosek krakowskich posłów wyrażono zgodę, aby Karol Ferdynand pozostał na opactwie na okres kolejnych dwóch lat, czyli do następnego sejmu; Z. T r a w ick a, Sejm z roku 1639, SH 1972, R. XV, z. 4 (59), s. 571, $576,580-581$.

${ }^{175}$ PSB, t. XII/1, s. 87. Opactwo tynieckie należało, obok czerwińskiego, do opactw najbogatszych; J. D zi ę gi elew ski, Izba poselska w systemie wladzy Rzeczpospolitej w czasach Wladyslawa IV, Warszawa 1990 , s. 60-70. 
Zabiegi o zabezpieczenie sytuacji materialnej nie ustawały i w 1640 r. król przeprowadził wybór brata na biskupstwo płockie ${ }^{176}$. Było ono zaliczane do jednego $\mathrm{z}$ zamożniejszych $\mathrm{w}$ Rzeczpospolitej ${ }^{177}$. Pod względem dochodów w XVI w. biskupstwo to zajmowało czwarte miejsce w Rzeczpospolitej ${ }^{178}$. Wybór spotkał się z protestami szlachty, niechętnej nadawaniu stanowisk senatorskich królewiczom. W zamian za odstąpienie praw do ubiegania się o koronę, na sejmie koronacyjnym 1649 r. Jan Kazimierz wystąpił o nadanie królewiczowi Karolowi dwóch opactw ${ }^{179}$. Znalazło to wyraz w konstytucji Konsens na konferowanie dwojga Opactw Królewicowi Imci Karolowi ${ }^{180}$. Brat króla uzyskał wówczas wakujące opactwo mogilskie, drugim miało być to, które jako pierwsze się zwolni ${ }^{181}$.

Tabela 6

\begin{tabular}{|c|c|c|c|c|}
\cline { 2 - 5 } \multicolumn{1}{c|}{} & $\begin{array}{c}\text { Opactwo } \\
\text { czerwińskie }\end{array}$ & $\begin{array}{c}\text { Opactwo } \\
\text { tynieckie }\end{array}$ & Biskup plocki & $\begin{array}{c}\text { Opactwo } \\
\text { mogilskie }\end{array}$ \\
\hline $\begin{array}{c}\text { Karol Ferdynad Waza } \\
\text { (ur. 1613 r.) }\end{array}$ & $1633-1641$ & $1635-1641$ & $1640-1655$ & $1649-1655$ \\
\hline
\end{tabular}

Szybka kariera duchowna Michała Jerzego Poniatowskiego przypadła na lata następujące po elekcji monarszej jego starszego brata Stanisława na tron polski (7 IX $1764 \mathrm{r}$.) ${ }^{182}$. Nominacje na opata komendatoriusza czerwińskiego uzyskał od króla już 15 listopada tego roku. W 1768 r. zostal dziekanem królewskiej kolegiaty św. Jana w Warszawie. Biskupstwo płockie otrzymał we wrześniu 1773 r., zaś ingres do diecezji miał miejsce dopiero w 1776 r. ${ }^{183}$ Rok wcześniej - 4 IV 1775 r. - przyjąl koadiutorię biskupstwa krakowskiego. Diecezję krakowską otrzymal w zarząd 9 II 1782 r., po odsuniętym z powodu choroby psychicznej biskupie Kajetanie Sołtyku,

${ }^{176}$ Listy Władysława IV wstawiającego się za bratem, zob. Pomniki dziejów Polski wieku siedemnastego, t. 1, wyd. A. Podgórski, Wroclaw 1840 , nr 21 s. 37 ; nr 22, s. 39-40; nr 27, s. $56-57$.

${ }^{17}$ Sejm 1641 r. aprobowal wybór uchwaleniem konstytucji Konsens na Biskupstwo Plockie, VL, IV, f. 4-5, pkt 5. Królewicz objąl je dopiero w 1644 r., zob. J. Seredyka, Rzeczpospolita..., s. 203, przyp. 94; PSB, XII/1, s. 86.

${ }_{178}$ Ks. B. K u mor, Historia Kościola, cz. 5, s. 114.

179 Slownik Geograficzny Królestwa Polskiego, t. VI, red. B. Chlebowski, W. Walewski, Warszawa 1885, s. 589, s.v. Mogila (autor Dr. M. Maciszewski); A. S. R a ziwiłl, Pamietnik..., t. 3, s. 223, 232 .

${ }_{180} \mathrm{VL}, \mathrm{VI}, \mathrm{f} .27$, pkt 15 .

${ }^{181}$ L. Cie śl a k, Sejm warszawski w 1649/50 roku, Wrocław-Warszawa-Kraków-Gdańsk 1978, s. 31 .

${ }^{182}$ Ks. M. G r z y b ow sk i, Kościelna dzialalność Michala Jerzego Poniatowskiego biskupa plockiego 1773-1785, [w:] Studia $z$ historii kościola w Polsce, Warszawa 1983, s. 28.

${ }^{183}$ K. Zi en k owsk a, Stanislaw August Poniatowski, s. 241. 
i zarządzał nią do $1791 \mathrm{r}$. Opozycja antykrólewska sprzeciwiała się tej decyzji uważając, iż faktycznym powodem uzyskania tej godności było dążenie Poniatowskiego do zagarnięcia dochodów bogatego biskupstwa ${ }^{184}$. W listopadzie $1784 \mathrm{r}$. nadano mu komendatoryjne opactwo tynieckie przynoszące również duże dochody. Rok później objął archidiecezję gnieźnieńską (ingres w Gnieźnie do katedry nastąpil 9 IX 1789 r. $)^{185}$.

Tabela 7

\begin{tabular}{|c|c|c|c|c|c|c|c|}
\cline { 2 - 7 } \multicolumn{1}{c|}{} & $\begin{array}{c}\text { Komen- } \\
\text { datoriusz } \\
\text { opactwa } \\
\text { czerwiń- } \\
\text { skiego }\end{array}$ & $\begin{array}{c}\text { Dziekan } \\
\text { kolegiaty } \\
\text { św. Jana } \\
\text { w War- } \\
\text { szawie }\end{array}$ & $\begin{array}{c}\text { Biskup } \\
\text { płocki }^{a}\end{array}$ & $\begin{array}{c}\text { Koadiu- } \\
\text { tor bis- } \\
\text { kupstwa } \\
\text { krakow- } \\
\text { skiego }\end{array}$ & $\begin{array}{c}\text { Biskup } \\
\text { krakow- } \\
\text { ski }\end{array}$ & $\begin{array}{c}\text { Komen- } \\
\text { datoriusz } \\
\text { opactwa } \\
\text { tyniec- } \\
\text { kiego }\end{array}$ & $\begin{array}{c}\text { Arcy- } \\
\text { biskup } \\
\text { gniez- } \\
\text { nieński }\end{array}$ \\
\hline $\begin{array}{c}\text { Michal Jerzy } \\
\text { Poniatowski } \\
\text { (ur. 1736) }\end{array}$ & $1764-1794$ & $1768-1784$ & $1773-1785$ & 1775 & $1775-1791$ & $1784-1794$ & $1785-1794$ \\
\hline
\end{tabular}

${ }^{a}$ W tym samym roku, wcześniej, został komendatoriuszem biskupstwa płockiego.

4.2.3. Synowie króla Zygmunta III zwracali się do sejmików o poparcie ich starań na sejmie o uzyskanie prowizji.

Zdarzało się, iż małżonka króla nie otrzymywała przyshugujących dochodów z przyznanych jej dóbr oprawnych, gdyż znajdowały się one w ręku szlacheckich posesorów.

- W takiej sytuacji znalazła się żona Jana Kazimierza - Ludwika Maria. Aby zapewnić jej środki na utrzymanie, sejm 1649 r. przyznal jej w Koronie kwotę 49 tys. zł, zaś w Wielkim Księstwie Litewskim 24 tys. zl, z dóbr, które pierwsze zawakują. Nadania te miały charakter czasowy. Królowa mogła pobierać z nich dochody do czasu, w którym intraty $\mathrm{z}$ dóbr oprawnych nie powrócą do jej $\mathrm{raqk}^{186}$. Za wydatki poniesione przez królową na rzecz państwa (na potrzeby nasze) sejm 1659 r. potwierdzil zapisy sum na jej rzecz poczynione na dobrach dziedzicznych ruchomych i nieruchomych w Koronie i na Litwie ${ }^{187}$. Ekonomie będące w ręku Ludwiki Marii uległy w czasie potopu szwedzkiego zniszczeniom wojennym, zaś część została zniesiona. Aby zrekompensować $z$ tego tytułu stratę $w$ dochodach, sejm przyznał jej wpływy finansowe $\mathrm{z}$ żup bocheńskich $\mathrm{i} \mathrm{z}$ komór solnych w Gronkach i Dobrzykowie prawem dożywotnim ${ }^{188}$.

${ }_{184}$ PSB, t. XXVII/3, s.v. Poniatowski Michal Jerzy h. Ciolek (autor Z. Zi elin s k a), s. 464.

${ }^{185}$ Ks. M. G r zy bow sk i, Kościelna dzialalność..., s. 29, przyp. 48. Pod względem dochodowości diecezja gnieźnieńska zajmowała pierwsze miejsce, ks. B. K u mo r, Historia Kościola, cz. 5, s. 114 .

186 VL, IV, f. 285: Opatrzenie stolu Krolowey ley Mci.

187 Ibidem, f. 593.

${ }^{188}$ Loc. cit. 
Na sejmie 1768 r. uregulowano kwestię utrzymania potomstwa króla Stanisława Augusta. Postanowiono, iż przyszli jego synowie otrzymają corocznie po 12 tys. czerwonych zł - każdy, natomiast córki - połowę tej kwoty ${ }^{189}$.

4.2.4. kolejnym źródłem finansowania członków rodziny były zapisy sum dokonywane przez władcę.

- Zygmunt II August zapisal w testamencie prawa do dóbr i sum neapolitańskich swym siostrom Annie, Katarzynie i Zofii, z zastrzeżeniem, iż po ich śmierci nie przejdą one na ich potomstwo, lecz staną się wierzytelnością Rzeczpospolitej ${ }^{190}$. Po śmierci sióstr królewna Anna przejęła prawo do sum neapolitańskich, stając się jedyną ich dziedziczką ${ }^{191}$. Zygmunt III Waza, wstępując na tron polski, przyrzekł w paktach konwentach darować skarbowi Rzeczpospolitej i Wielkiego Ks. Litewskiego pewne dobra, sumy pieniężne i pensje neapolitańskie z Księstw Bari i Rosano oraz myta Foggia $^{192}$. Na sejmie koronacyjnym 1588 r. ponownie zrzekł się ich oficjalnie, w imieniu swoich dzieci i następców, na rzecz Rzeczpospolitej ${ }^{193}$. Po śmierci Anny Jagiellonki Rzeczpospolita stała się właścicielką sum, natomiast król stał się ich użytkownikiem. Za zgodą stanów ${ }^{194}$, przejął przypadającą nań część wypłacanych procentów od sum. Dochody $\mathrm{z}$ nich wpływały nieregularnie.

Monarcha nie miał prawa dysponowania sumami pochodzącymi z procentów od pożyczki udzielonej przez królową Bonę monarsze hiszpańskiemu ${ }^{195}$. Mimo to w $1626 \mathrm{r}$. rozporządził sumami jak dziedziczną, wyłączną własnością, zapisując je synowi z pierwszego małżeństwa - królewiczowi Władysławowi i drugiej swej małżonce - królowej Konstancji ${ }^{196}$. Po śmierci królowej Konstancji, jej synowie Jan Kazimierz i Karol Ferdynand potraktowali sumy

189 VL, VII, f. 609: Pensya dwom Krolewiczom Polskim, Xaweremu y Karolowi.

190 J. B a r to s ze wi c z, Sumy neapolitańskie, [w:] Dziela..., t. VIII: Studja historyczne i literackie, t. I, Kraków 1880, s. 203; W. C z e r m a k, Jan Kazimierz. Studya nad jego życiem i charakterem, [w:] Z czasów Jana Kazimierza. Studya historyczne, Lwów 1893, s. 109. Zygmunt II August pobierał w latach 1561-1572 regularnie procenty od sumy pożyczonej przez królową Bonę Filipowi II hiszpańskiemu; była to kwota ok. 43 tys. dukatów rocznie, M. B og u cka, Anna Jagiellonka, Wrocław-Warszawa-Kraków 1994, s. 128.

191 Zofia zmarła bezdzietnie w 1575 r. zaś Katarzyna zmarła w 1583 r.; jej synem był Zygmunt Waza, zob. J. Bartoszewicz, Sumy neapolitańskie, s. 270, 274-275. Dochód z sum neapolitańskich wynosil w 1596 r. ok. 30 tys. dukatów, otrzymała je Anna Jagiellonka; zob. A. Fili pczak - K ocu r, $Z$ dziejów skarbu nadwornego za Zygmunta III Wazy, s. 64, przyp. 63, z odesłaniem do: CIGA, Kijew, f. 1, nr 2, k. 188.

192 VL, II, f. 1098, pkt 8, zd. drugie.

193 J. B artoszewicz, Sumy neapolitanskie, s. 276, z odesłaniem do: Liber inscriptionum et privilegiorum, w Metryce Koronnej, ks. 181, w akcie króla Michała.

194 J. B a r t o s ze wi c z, Sumy neapolitanskie, s. 276-277; W. Cze r m a k, Jan Kazimierz..., s. 109.

195 J. B artoszewicz, Sumy neapolitańskie, s. 277.

196 W. Cze rma k, Jan Kazimierz..., s. 110. 
jako spadek, zrzekając się swoich części na rzecz siostry Anny Katarzyny ${ }^{197}$. Za panowania Władysława IV pieniądze przychodziły regularnie ${ }^{198}$; po jego śmierci przypadły one na rzecz Jana Kazimierza ${ }^{199}$.

- W 1593 r. król, przekazując starostwo lubelskie podskarbiemu wielkiemu koronnemu Janowi Firlejowi z Dąbrowicy, nałożył nań obowiązek placenia królowej Annie na jej prywatny użytek rocznie kwoty 5 tys. $\mathrm{z}^{200}$.

Podstawą utrzymania królewicza Władysława było uposażenie w wysokości ok. 50 tys. zł otrzymywane od ojca, które nie wystarczało jednak na pokrycie wydatków królewicza ${ }^{201}$.

Michał Korybut Wiśniowiecki wyznaczył swej matce Gryzeldzie dochód dożywotni na ekonomii samborskiej. Była to kwota w wysokości 50 tys. $\mathrm{z}^{202}$. Decyzja króla spotkała się ze sprzeciwem szlachty argumentującej, iż była ona sprzeczna $\mathrm{z}$ przepisem zakazującym obciążania pensją ekonomii królewskich.

Sejm radomski 1768 r. obdarzył Kazimierza Poniatowskiego kwotą 1 tys. dukatów, co było rekompensatą za opatrzenie spalonych w $1766 \mathrm{r}$. Sokala i Stojanowa ${ }^{203}$. Stanisław August Poniatowski przyznal w 1794 r. bratu Kazimierzowi miesięczny zasiłek wysokości 500 dukatów, wypłacany do 1798 r. $^{204}$

Pensje ze skarbu państwa wysokości 6 tys. dukatów otrzymywal od króla jego bratanek, a syn Kazimierza Poniatowskiego - Stanisław. Początkowo były pokrywane ze skarbu państwa niektóre jego wydatki reprezentacyjne ${ }^{205}$.

4.3. Monarchia w szlacheckim państwie była elekcyjna, w związku z czym powstawal problem czasu trwania uprawnień majątkowych rodziny królewskiej. Rozwiązania przysługujące uprawnionym mogły być różne. Mianowicie:

197 J. Bartoszewicz zwraca uwagę na fakt, iż bracia mimo zrzeczenia się praw na rzecz siostry otrzymywali należne pieniądze od dworu hiszpańskiego (ibidem, s. 282).

198 Ibidem, s. 279.

${ }^{199}$ Szacuje się, iż dochody te wynosily trzydzieści kilka tysiecy dukatów rocznie... W 1650 r. wskutek decyzji wicekróla neapolitańskiego uległy one zmniejszeniu o $1 / 3$ część; w efekcie Jan Kazimierz i Filip Wilhelm Neuburski (mąż Anny Katarzyny Wazy) otrzymywali po 11428 dukatów, czyli około 70 tys. zł. rocznie każdy; zob. W. C ze r m a k, Jan Kazimierz..., s. 110. Umierając Jan Kazimierz zapisał procenty od sum neapolitańskich siostrze Ludwiki Marii - Annie Gonzaga księżniczce de Nevers; zob. J. B a r t o s z ew i c z, Sumy neapolitańskie, S. 284.

${ }^{200}$ W. P a łu cki, Drogi i bezdroża..., s. 192, z odesłaniem do MK, 138, f. 28; autor podaje, iż w poźniejszym wpisie do MK z t.r. (f. 275) wpisana jest kwota 3 tys. zł (tria millia florenorum).

${ }^{201}$ W. Cza pli ńs k i, Wladyslaw IV i jego czasy, s. 69.

${ }^{202}$ Pisma do wieku $i$ spraw Jana Sobieskiego, t. I, cz. II, nr 365, s. 989: Exorbitantie ad correcturum Seymu Anni 1672. Zob. też T. Korzo n, Dola i niedola Jana III Sobieskiego 1629-1696, t. III, Kraków 1898, s. 163.

${ }^{203}$ PSB, t. XXVII/3, s. 448, s.v. Poniatowski Stanislaw h. Ciolek (autor J. M i chalski).

${ }^{204}$ Ibidem, s. 451.

205 Ibidem, s. 482. 
- dożywotnie;

- do końca panowania ówczesnego monarchy;

- do objeccia tronu przez nowoobranego wladcę;

$\checkmark$ do chwili wykupu.

Problem ten pojawił się po śmierci Zygmunta III Wazy, który pozostawił liczne potomstwo, inaczej niż Henryk Walezy i Stefan Batory, którzy dzieci nie mieli. Sprawą zająl się sejm konwokacyjny (22 VI - 17 VII 1632 r.), podczas którego doszło do różnicy zdań: czy środki na swoje utrzymanie potomkowie zmarłego władcy mają otrzymywać do czasu elekcji nowego, czy do czasu pogrzebu jego poprzednika ${ }^{206}$. Przyjęto pierwsze rozwiązanie: uchwalona konstytucja stanowiła, iż dochody dóbr stołowych (tak koronnych, jak i litewskich) na utrzymanie mogą pobierać do chwili elekcji nowego króla. Wprowadzono zastrzeżenie, iż podskarbiowie nie mogą żadnymi długami obciążać dóbr stolowych, a na sejmie elekcyjnym powinni zlożyć sprawozdanie $z$ dokonanych wydatków ${ }^{207}$. Po śmierci Wladysława IV konfederacja generalna warszawska postanowiła, iż dochody z dóbr stolowych królewskich przysługują królowej wdowie do dnia pogrzebu władcy ${ }^{208}$.

Po śmierci Michała Korybuta Wiśniowieckiego sejm konwokacyjny 1674 r., ze względu na bezpotomność zmarłego, uchwalił dla jego małżonki królowej Eleonory, wdowią prowizję na okres jednego roku, w wysokości 200 tys. $\mathrm{z}^{209}$.

Synom zmarłego króla Jana III Sobieskiego i jego żonie zagwarantowano w paktach konwentach Augusta II nienaruszalność dóbr zarówno dziedzicznych, jak i dóbr Rzeczpospolitej będących w ich posiadaniu ${ }^{210}$. W paktach konwentach ostatniego bezkrólewia $(1764$ r.) nie znajdujemy żadnych postanowień odnośnie do zabezpieczenia praw majątkowych potomstwa zmarkego Augusta III. Dopiero sejm 1768 r. udzielił sukcesorom domu saskiego gwarancję zachowania dóbr dziedzicznych - tak dzierżaw wieczystych, jak i zawartych na czas oznaczony ${ }^{211}$.

${ }^{206}$ A. S. R adziwiłl, Pamietnik..., t. 1, s. 178.

${ }^{207}$ Konfederacya generalna omnium ordinum..., VL, III, f. 734, pkt 48. Na konstytucję zwróciła uwage U. A ugustyniak, Wazowie i ,królowie rodacy". Studium wladzy królewskiej $w$ Rzeczypospolitej XVII wieku, Warszawa 1999, s. 159. Sprawa ta zajełła dużo czasu z uwagi na protest posła $z$ województwa sieradzkiego, zob. A. S. R a d zi wi ił, Pamietnik..., t. 1, s. 134.

${ }^{208} \mathrm{VL}, \mathrm{IV}, \mathrm{f} .164$.

${ }^{209} \mathrm{VL}, \mathrm{V}$, f. 218; pieniądze miały pochodzić z dochodów $z$ dóbr stolowych żupnych ekonomicznych y celnych, $1 / 3$ tej kwoty miała pochodzić ze skarbu litewskiego. Zob. T. K or zon, Dola i niedola..., t. III, s. 448; K. M a tw ij ow s k i, Pierwsze sejmy z czasów Jana III Sobieskiego, Wroclawskie Tow. Nauk., ser. A, nr 187, Wrockaw 1976, s. 22, 27, 193, 229.

$210 \mathrm{VL}, \mathrm{VI}, \mathrm{f} .23$. Nałożono na nich obowiązek, aby adminstratorami i ekonomami w tych dobrach była polska szlachta osiadła.

211 VL, VII, f. 608-609: Assekuracya possessyi Domowi Saskiemu w Polszcze. Gwarancją objęto: nabytki potwierdzone konstytucją z 1726 r.; kontrakty z 1736 r. na wieczystą dzierżawę na grunt na Szolcu i z 1761 r. na dzierżawę czasową na wyspe Ostrow nazwanq. 
Zdarzało się, iż przyznawano pensję synom zmarłego króla pod rządami nowego monarchy. Starania o uzyskanie środków materialnych na utrzymanie podjąl, po elekcji Stanisława Augusta Poniatowskiego, Karol Chrystian Józef - syn zmarłego króla Augusta III Sasa. Zaopatrzenie takie przyznał mu sejm 1768 r., wyznaczając roczne pensje w wysokości 12 tys. dukatów jemu i jego bratu Ksaweremu ${ }^{212}$. Powyższa kwota miała być wyplacana w dwóch ratach, co pół roku. Pierwszy sejm rozbiorowy $1775 \mathrm{r}$. wyznaczył na pensję dla obu królewiczów kwotę w wysokości 268 tys. $\mathrm{zt}^{213}$, zaś sejm $1776 \mathrm{r}$. zmniejszył ją do 178666 zł 20 gr $^{214}$. Sejm grodzieński 1793 r. powrócił do kwoty 268 tys. zł, która miała być wypłacana dożywotnio obu braciom. Ostatni sejm Rzeczpospolitej określił ponadto pobory, jakie miala otrzymywać jego żona i córka na wypadek przeżycia królewicza Karola Chrystiana Józefa ${ }^{215}$.

\subsection{Podmiot uposażający.}

4.4.1. Decyzje o zapewnieniu środków na utrzymanie rodziny królewskiej podejmowane były $z$ inicjatywy władcy. On był głównym decydentem. Tak było w przypadku zakupu dóbr, nadań ziemskich pod różnymi tytułami, wykupu królewszczyzn z zastawu, nadań w użytkowanie, w dzierżawę czy cesji dóbr królewskich trzymanych przez osobę trzecią ${ }^{216}$. Podobnie było z nadaniami dochodów ze starostw czy związanymi z pełnieniem godności duchownych. $Z$ uwagi na to, że następowało to $\mathrm{z}$ naruszeniem obowiązujących zwyczajów, decyzje te musiały uzyskać jednak zatwierdzenie sejmu, co po dłuższych sporach dokonywano na jego forum. Król występował do sejmu $\mathrm{z}$ inicjatywą ustanowienia uposażenia dla swojego potomstwa. Tak bylo w 1632 r.: Zygmunt III, uzyskawszy pożądane decyzje, zrezygnował na rzecz Rzeczypospolitej $\mathrm{z}$ czerpanych dotąd dochodów z mennicy. Zygmunt III, jak i nastẹpni monarchowie, dokonywał zakupu dóbr ziemskich; umowy takie były post factum potwierdzane przez sejm albo też nie uzyskiwały one takiej legalizacji. Król przyznawał swoim bliskim pensję m.in. w postaci kwot, które dzierżawcy królewszczyzn winni byli płacić na rzecz poszczególnych

${ }^{212}$ VL, VII, f. 609: Pensya dwom Krolewiczom Polskim, Xaweremu y Karolowi, PSB, t. XII/1, s. 88, s.v. Karol Chrystian Józef (autor R. W. W ołos zy ń s k i).

${ }^{213}$ VL, VIII, s. 99.

214 Ibidem, f. 891.

${ }^{215}$ Małżonka miała otrzymywać połowę uposażenia męża królewicza, z kolei ich córka 36 tys. zl, VL, X, Konstytucje sejmu grodzieńskiego z 1793 r., wyd. Z Kaczmarczyk przy współudziale J. Matuszewskiego, M. Szczanieckiego i J. Wąsickiego, Poznań 1952, s. 335, pkt 29: Pensja dożywotnia dla ksiqżż saskich a królewiczów polskich; zob. PSB, XII/1, s. 89.

${ }^{216}$ T. Zielińska, Magnateria..., s. 34, 80, 83; J. Matuszewski, Die Verpfändung der Krongüter und das Nutzungssystem der Herrschftsgüter der Regierendden in Polen des 15. Und 16. Jahrhunderts, [w:] Polen und Osterreich in 16 Jahrhundert, hrsg. von W. Leitsch und S. Trawkowski, Wien-Köln-Weimar 1997, s. 58-59. 
dzieci królewskich. Monarcha miał szeroką gamę możliwości zapewnienia swojej rodzinie środków na utrzymanie.

4.4.2. $W$ źródłach napotykamy na informacje, $z$ których wynika, iż w pewnych sytuacjach o nadaniu zaopatrzenia czlonkom rodziny królewskiej decydowal sejmu. $\mathrm{Na}$ sejmie warszawskim $1620 \mathrm{r}$. stany koronne i litewskie wyrazily zgodę na oddanie królewiczowi Władysławowi w administracje i użytkowanie ziem zdobytych w wyniku dymitriad ${ }^{217}$. Z uwagi na niewystarczające na utrzymanie dochody królewicza sejm w $1626 \mathrm{r}$. przyznał mu określonej wysokości zaopatrzenie ${ }^{218}$.

Aby zapewnić środki na utrzymanie królowej nie mającej dochodów z oprawy znajdującej się w rękach prywatnych, król zwracał się do sejmu o przyznanie jej uposażenia do czasu powrotu dóbr oprawnych. Sejm przyznawał określonej wysokości sumy z dóbr królewskich, które zawakują ${ }^{219}$. Król Władysław IV w czasie obrad sejmowych podejmował starania o nadanie bratu jako źródła utrzymania godności duchownych, na co sejm wyrażał zgodę (1633, 1640, 1649 r.).

Wstępujący na tron władca winien był rozdać starostwa, z których dochody dotychczas czerpał. W 1676 r. sejm odstąpił od tego zwyczaju, zezwalając królowi i jego małżonce na ich dalsze trzymanie.

Ostatecznie w paktach conwentach z 1764 r. zezwolono nowo wybranemu królowi na zakup dóbr ziemskich do określonej wartości, bez potrzeby uzyskania od sejmu na to zgody. Problem zaopatrzenia finansowego potomków ostatniego króla uregulowano na sejmie 1768 r., wyznaczając im na przyszłość określonej wysokości roczne pensje, co nie położyło kresu różnym formom finansowania pozostałych krewnych przez władcę.

\section{5}

Ustawodawca był uzależniony od postępowania królewskiego, które sankcjonowal po fakcie.

5.1. Naruszenie prawa zwyczajowego zakazującego nabywania dóbr ziemskich przez członka rodziny królewskiej, poprzez zakup dóbr żywieckich w 1624 r., doprowadziło do ostrego konfliktu między królem a szlachtą zakończonego uchwaleniem na sejmie $1631 \mathrm{r}$. dwóch konstytucji: $O$ dobrach ziemskich dziedzicznych i $O$ dobrach żywieckich ${ }^{20}$. Pierwsza z konstytucji, aby uniknąć $w$ przyszłości podobnych przypadków naruszeń prawa, wprowadziła generalny zakaz kupowania, darowizn, zastawu lub pozyskiwania

${ }_{217}$ Ordynacya Prowincyi od Moskwy rekuperowanych, VL, III, f. 368-371.

${ }^{218}$ Ibidem, III, f. 495: Auctia prowizyi stolu Krolewicza I. Mści Wladyslawa.

219 VL, IV, f. 285: Opatrzenie stolu Krolowey ley Mci.

220 VL, III, f. 666, 667-668. 
w jakikolwiek inny sposób dziedzicznych dóbr ziemskich przez członków rodziny królewskiej ${ }^{221}$. Druga $\mathrm{z}$ nich, odnosząca się do aktu zakupu dóbr żywieckich, akceptowała doraźne złamanie obowiązującego prawa zwyczajowego, dozwalając królowej trzymać wspomniane dobra aż do chwili wykupu ich przez Rzeczpospolitą bądź osobę prywatną (szlachcica koronnego lub litewskiego) ${ }^{222}$. W przypadku śmierci królowej suma miała przypaść jej synom. Starostwo traktowane było przez rodzinę królewską jako wlasność. Po śmierci królowej, w ramach rozliczeń rodzinnych, uzyskal je królewicz Karol Ferdynand, po nim jego brat Jan Kazimierz ${ }^{223}$.

$\mathrm{Na}$ wspomnianym sejmie, w dyplomie ad archiwum Zygmunt III zobowiązał się, iż królewicz Jan Albert nie będzie nabywał dóbr ziemskich ${ }^{224}$. Panujący nie chciał upubliczniać swego ustępstwa. Sejm 1633 r., zatwierdzając objęcie biskupstwa krakowskiego przez królewicza, zakazał nabywania dóbr ziemskich pod jakimkolwiek tytulem ${ }^{225}$.

Mimo obowiązywania konstytucji $O$ dobrach ziemskich dziedzicznych monarchowie nabywali posiadłości ziemskie. Kupna dokonane przez Augusta II Sasa usankcjonowal, po fakcie, sejm w 1726 r. konstytucją sejmową ${ }^{226}$.

${ }^{221}$ Ziemskie dobra szlacheckie mogły nabywać jedynie osoby, które juri Terrestri mere podlegajq, et per omnia gaudent aequalitatae et paritate iuris et poene. W stosunku do podmiotów uprawnionych do nabywania dóbr ziemskich użyto sformułowania, iż są to osoby, które żadney $w$ personach swoich preeminencyi nie zaciagaja, czyli nie mogli to być czlonkowie rodziny królewskiej; uwage na to zwrócił J. M a z u rkiew ic z, Ustawy amortyzacyjne w dawnej Polsce, Pamiętnik Historyczno-Prawny [Lwów] 1933, t. XII, z. 2, s. 29. Zabroniono królowi dokonywania darowizn, kupna, zastawu czy w jakichkolwiek inny sposób nadań na rzecz innych osób niż szlachta. Odnosiło się to również do dóbr, które król otrzymał prawem kaduka, zapisu czy darowizny, VL, III, f. 666.

${ }^{222}$ Wykupu Żywca dokonał w 1676 r., Jan Wielopolski - podkanclerzy koronny, ożeniony z siostrą królowej Marii Kazimiery - Marią Anną de la Grange, margrabianką d'Arquien, zob. Exemptio Zywca, VL, V, f. 358-359. Zdaniem S. Cynarskiego, dobra zostały wykupione w 1678 r.; zob. te n ż e, Poczq̨iki kariery rodziny Wielopolskich, [w:] Spoleczeństwo staropolskie, t. 2, red. A. Wyczański, Warszawa 1979, s. 155, bez podania źródła; podobnie S. C i a ra, Senatorowie i dygnitarze..., s. 130.

${ }^{223}$ K. Ch ła p ow s ki, Spór o kupno dóbr żywieckich przez królowa Konstancje w latach 1624-1631, $\mathrm{KH}$ 1997, R. CIV, z. 2, s. 10. Jan Kazimierz zapisal je w testamencie szwagierce Annie Gonzadze, ta $z$ kolei scedowała je zięciowi Henrykowi Ludwikowi de Bourbon; zob. U. A ugustyniak, Wazowie i ,królowie rodacy", s. 135.

${ }^{224} \mathrm{~J}$. Seredyka, Rzeczpospolita w ostatnich latach panowania Zygmunta III (1629-1632). Zarys wewnętrznych dziejów politycznych, Studia i Monografie [Opole] 1978, $\mathrm{nr}$ 62, s. 119.

${ }^{225}$ Dobr ziemskich niiakim sposobem nabywać nie ma: czego Urzędy wszelkie przestrzegać będq, aby takowych inscriptiones nie przyimowali, sub poena peculatus ad cujusvis instantiam, in Iudicio Tribunalitio inter officij repetenda: y zapisy takowe żadney wagi mieć nie bedq...; VL, III, pkt 19: Konsens na Biskupstwo Krakowskie, f. 792 (1633 r.); IV, f. 5, pkt 3: Konsens na Biskupstwo Plockie (1641 r.).

${ }^{226}$ Palac nasz Morsztynowski z gruntami i przyleglościami do niego należqcemi, VL, VI, f. 447, pkt 8. Jak pisze J. Sta szewski, był to osobisty sukces króla; te nże, August II Mocny, Wrocław-Warszawa-Kraków 1998, s. 240. 
Postanowieniami objęto również wszystkie inne palace, place, grunta tudzież y rezydencye, do których prawo własności uzyskał władca. Po królu dziedziczyć je mogli jego krewni. Powyższe nabytki uzyskały sejmową gwarancję nienaruszalności w 1768 r.; objęto nią wówczas również te dobra, które nie posiadały dotychczas takiej aprobaty ${ }^{227}$.

Naruszanie zakazu kupowania majątków ziemskich przez panujących spowodowało, że w $1764 \mathrm{r}$. w paktach konwentach zezwolono królowi na kupno dóbr nie przekraczających wartości $15 \mathrm{mln}$ złp, bez potrzeby ubiegania się o zgode sejmu ${ }^{228}$. W kwestii ich dziedziczenia pakta przewidywaly dwie sytuacje. Pierwsza - gdy byli synowie; prawo sukcesji tych dóbr przyshugiwało tylko $\mathrm{im}^{229}$. Druga - gdy nie było męskiego potomstwa; wówczas $w$ dobrach mogła być osadzona córka królewska, jednakże nie mogła ona ich dziedziczyć. Gdy wychodziła za mąż, przysługiwało jej prawo do uzyskania ze strony najbliższych krewnych splaty $z$ majątku ziemskiego.

Przedstawiciele rodziny królewskiej dokonywali ze swoich środków wykupu dóbr zastawnych, stając się zastawnikiem. Chcąc zabezpieczyć pieniądze, które królowa wyłożyla na wykupienie, sejm warszawski 1616 r. uchwalit konstytucję Warunek summy dziesięciu tysięcy zlotych na Oniszkach. Uznano wymienione dobra za obciążone kwotą, za którą zostały wykupione, przy jednoczesnym utrzymaniu królowej $w$ posiadaniu nieruchomości. Zapisaną sumą mogła ona dysponować według własnej woli ${ }^{230}$. Aby uniknąć na przyszłość podobnych sytuacji, sejm w $1631 \mathrm{r}$. wprowadzil przepis zabraniający członkom rodziny królewskiej nabywania dóbr ziemskich będących w zastawie $^{231}$. Przepis ten nie był przestrzegany, o czym świadczą wykupy dokonywane przez Jana III Sobieskiego.

${ }_{227}$ Assekuracya possessyi Domowi Saskiemu w Polszcze, VL, VII, f. 608-609.

${ }^{228}$ VL, VII, f. 201. Z kolei w paktach konwentach sejmu grodzieńskiego 1793 r. zezwolono królowi, za wiedzą Rady Nieustającej i z zachowaniem formalności prawnych, nabyć dla siebie lub swego potomstwa dziedziczne dobra ziemskie do wysokości $10 \mathrm{mln}$. Sukcesja tych dóbr przechodziła tylko na potomków męskich. W przypadku ich braku, dobra przechodziły na linię żeńską. Prawo do dziedziczenia nie przysługiwało jednak w sytuacji, gdy córki przeniosły się za granicę lub ich mężowie objęli tam władzę. Wówczas dobra miały być skupione, według ich wartości, przez krewnych, a w razie ich braku - przez skarb Rzeczypospolitej, następnie zaś odsprzedane obywatelom Rzeczypospolitej. Gđyby z kolei syn króla uzyskał władzę poza Rzecząpospospolią, to trzymane przez niego dobra dziedziczne podlegały wykupieniu, VL, t. X: Konstytucje sejmu grodzieŕskiego z 1793 roku, wyd. Z. Kaczmarczyk przy współudziale J. Matuszewskiego, M. Szczanieckiego, J. Wąsickiego, Poznań 1952, s. 113-114.

${ }^{229}$ VL, VII, f. 201: ...które to dobra successoribus masculis tylko cedere powinny...; loc. cit..

${ }^{230} \mathrm{VL}, \mathrm{III}$, f. 306, pkt 2.

${ }^{231}$ Dobra ziemskie dziedziczne, nec modo donationis, nec emptionis, albo hypotecae, neque quovis obligationis modo, aut aliquo alio jure, napotym dostawane bydz nie maiq...; ibidem, f. 666: $O$ dobrach ziemskich dziedzicznych. 
Zygmunt III nadawał uposażenia starostw członkom swojej rodziny, a następnie zabiegal na sejmie o ich usankcjonowanie. Nadanie przez Zygmunta III Brodnicy i Golubia na rzecz swojej żony, po długich staraniach zaaprobowal w 1631 r. sejm konstytucją ${ }^{232}$. Ustąpil zatem sejm na rzecz rodziny królewskiej, mimo ostrych sprzeciwów podnoszonych ustawicznie przez szlachtę $w$ tej sprawie. Starostwa te miały świadczyć wszystkie dotychczasowe ciężary względem państwa.

Ustawodawca zmierzal do ograniczenia praw potomstwa królewskiego do oprawy, na której był zabezpieczony posag królowej. Po śmierci matki prawo doń uzyskiwało potomstwo. Chcąc ograniczyć możliwości króla korzystania $z$ posagu żony na rzecz potomstwa i przeznaczyć dobra wchodzące w skład oprawy dla osób zasłużonych, sejm 1607 r. uchwalił konstytucje Zniesienie oprawy Krolowey Iey Mci zmarley, Malżonki naszey. Starostwa wchodzące w skład oprawy zwrócono wówczas do skarbu koronnego $^{233}$. W 1609 r. na sejmie wprowadzono przepis, iż żaden potomek rodziny królewskiej nie ma prawa sukcesji do dóbr, które należały do oprawy matki ${ }^{234}$. Zakaz sukcesji na dobrach oprawnych powtórzono w konstytucjach z 1638 r. - Oprawa K. I. M. Cecylii Renaty 235 , z 1646 r. - Oprawa Krolowey Iey Mci Ludowiki Maryi ${ }^{236} \mathrm{i}$ w następnych ${ }^{237}$. Niemniej jednak dochody z niektórych starostw oprawnych sejm przeznaczal na utrzymanie dzieci królewskich.

5.2. Konstytucje z 1576 r. i z 1607 r., określając ogólne warunki, jakie powinna spełniać osoba otrzymująca urząd publiczny czy dworski, stanowiły, iż winny to być osoby zasłużone, godne, korzystające $\mathrm{z}$ praw publicznych. $\mathrm{Z}$ kręgu tych osób nie wyłączono wyraźnie członków rodziny królewskiej.

Sejm był przeciwny nadawaniu przez monarchę godności kościelnych członkom rodziny królewskiej. Chcąc położyć kres takiej praktyce, w $1631 \mathrm{r}$. uchwalono konstytucje $O$ wakancyach, którą postanowiono, że duchowne $y$ świeckie beneficia et dignitates, które zostaną zwolnione, król może nadać członkom swojej rodziny tylko za zgodą sejmu. Uprawnionymi do ich uzyskania byli przedstawiciele stanu szlacheckiego korzystający $\mathrm{z}$ praw publicznych i niekarani ${ }^{238}$. W konstytucji odwołano się do wcześniejszych przepisów zakazujących nadawania urzędów osobom $\mathrm{z}$ rodów książęcych. Zygmunt III

${ }^{232}$ VL, III, f. 668 , pkt 7: Starostwa Brodnickie, y Golubskie.

233 VL, II, f. 1605, pkt 18.

${ }^{234}$ VL, II, f. 1666, pkt 13: Oprawa Królowej Iey Mci Konstancyi, zd. ostatnie.

${ }^{235}$ VL, III, f. 926 . Sejm 1647 r. uchwalił konstytucje Zniesienie reformacyi K. I. M. Cecylii, zob. VL, IV, f. 104.

${ }^{236} \mathrm{VL}, \mathrm{IV}$, f. 90.

${ }^{237}$ VL, V, f. 56: Oprawa Nayiaśnieyszey Krolowey Ieymci Eleonory (1670 r.); f. 551: Oprawa Nayiaśnieyszey Krolowey Imci Maryi (1678 r.); VI, f. 659: Oprawa Nayiaśn. Krolowey Ieymci (1736 r.).

238 VL, III, f. 669. 
na krótko przed śmiercią przeforsował nadanie królewiczowi Janowi Albertowi biskupstwa krakowskiego, co zostało zaaprobowane na sejmie koronacyjnym $1633 r^{239}$

\section{6}

Gdy w świadomości szlacheckiej utrwalił się pogląd, że królewszczyzny są panis bene merentium, zaś ideałem król, który nie dysponuje własnymi dochodami i jest uzależniony finansowo od szlacheckiego sejmu ${ }^{240}$, w szczególnym wówczas polożeniu materialnym znaleźli się obcy władcy elekcyjni. Wybrani na tron Rzeczpospolitej nie posiadali na jej obszarze dóbr rodowych. Byłoby zatem dziwne, gdyby nie zadbali o zapewnienie środków na utrzymanie swojej rodziny.

W ciągu calego okresu obserwujemy zmagania na linii król - szlachta. $Z$ jednej strony władca chciał uzyskać jak najwięcej dla siebie i swojej rodziny, aby stworzyć dla niej zaplecze materialne. Wobec braku uregulowań prawnych panujący podejmowali różne kroki dla osiągnięcia tego celu. $Z$ drugiej strony szlachta zabiegi te traktowała nieufnic, uchwalając po fakcie konstytucje mające położyć temu kres. Sprzeciwy szlachty nie powstrzymywały działań władców zmierzających do wamocnienia pozycji materialnej rodziny. $W$ trakcie zmagań król przeprowadzal $\mathrm{w}$ zasadzie swoją wolę, nie licząc się $\mathrm{z}$ wolą szlachty, uzyskując dopiero po czasie zatwierdzenie wcześniej podjętych decyzji naruszających prawo. Postępowanie władcy wpływało modyfikująco na ustawodawstwo sejmu. Mimo ustanawianych różnych ograniczeń, władca elekcyjny był personą, która na ogól uzyskiwała to, o co zabiegała, by zapewnić swoim bliskim środki utrzymania.

\footnotetext{
239 Ibidem, f. 791-792: Konsens na Biskupstwo Krakowskie.

${ }^{240}$ Znalazło to wyraz w publicystyce politycznej z okresu rokoszu Zebrzydowskiego: Niechajże to tak stanie o królu i o bogactwie jego, choćby bylo co więcej; które bogactwo ukazalbym być przyczynq zginienia i niewolej naszej, bo kiedybyśmy mieli króle ubogie, coby nie mu od nich, ale oni od nas potrzebowali, jako przeszlych czasów bylo, bywaliśmy w poszanowaniu, wolności nam trzymano, przysiegi nie gwalcono; wytargowaliśmy zawsze co na królu, kiedyby czego $u$ nas chcial, a teraz nie potrzebuje nas, ma sie jako pan...; Rewersal listu szlachcica jednego..., [w:] Pisma polityczne z czasów rokoszu Zebrzydowskiego 1606-1609, t. II: Proza, wyd. J. Czubek, Kraków 1918, s. 242. Zob. J. W ło d a r c z y k, Sejmiki jako szkola wychowania obywatelskiego (na przykladzie sejmików sieradzkiego i lęczyckiego), [w:] Dzieje kultury politycznej $w$ Polsce, red. J. A. Gierowski, Warszawa 1977, s. 73; S. O c h m a n n-S t a n is z ew sk a, Od stabilizacji do kryzysu wladzy królewskiej państwa Wazów, [w:] Studia z dziejów Polski $X V \backsim X V I I I$ wieku, red. A. Sucheni-Grabowska, M. Żaryn, Warszawa 1994, s. 223.
} 